\title{
Spatial distribution of soil erosion and suspended sediment transport rate for Chou-Shui river basin
}

\author{
Chin-Ping Lin ${ }^{1}$, Ching-Nuo Chen ${ }^{2}$, Yu-Min Wang ${ }^{1, *}$, Chin-Heng Tsai ${ }^{3}$ and Chang-Tai Tsai ${ }^{4}$ \\ ${ }^{1}$ Department of Civil Engineering, National Pingtung University of Science and Technology, Pingtung, Taiwan. \\ ${ }^{2}$ International Master's Program of Soil and Water Engg., National Pingtung University of Science and \\ Technology, Pingtung, Taiwan. \\ ${ }^{3}$ Department of Information Communication, University of Kang Ning, No. 188, Sec. 5, Anzhong Road, \\ Tainan 70970, Taiwan. \\ ${ }^{4}$ Department of Hydraulics and Ocean Engineering, National Cheng-Kung University, No. 1, \\ University Road, Tainan City 70101, Taiwan. \\ *Corresponding author.e-mail: wangym@mail.npust.edu.tw
}

In this study, a Physiographic Soil Erosion-Deposition Model (PSED) is applied for better management of a watershed. The PSED model can effectively evaluate the key parameters of watershed management: surface runoff discharge, suspended sediment transport rate, quantity of soil erosion, and spatial distribution of soil erosion and deposition. A basin usually contains multiple watersheds. These watersheds may have complex topography and heterogeneous physiographic properties. The PSED model, containing a physiographic rainfall-runoff model and a basin scale erosion-deposition model, can simulate the physical mechanism of the entire erosion process based on a detailed calculation of bed-load transportation, surface soil entrainment, and the deposition mechanism. With the assistance of Geographic Information Systems (GIS), the PSED model can handle and analyze extremely large hydrologic and physiographic datasets and simulate the physical erosion process without the need for simplification. We verified the PSED model using three typhoon events and 40 rainfall events. The application of PSED to Chou-Shui River basin shows that the PSED model can accurately estimate discharge hydrographs, suspended sediment transport rates, and sediment yield. Additionally, we obtained reasonable quantities of soil erosion as well as the spatial distribution of soil erosion and deposition. The results show that the PSED model is capable of calculating spatially distributed soil erosion and suspended sediment transport rates for a basin with multiple watersheds even if these watersheds have complex topography and heterogeneous physiographic properties.

\section{Introduction}

Taiwan is located in a tropic/subtropic area and as a result it is flood prone and is characterised by typhoons and torrential rains, which bring about two-thirds to three quarters of the annual rainfall amount. These storms are frequent during summer-autumn season (June-August) and have a mean precipitation of $2500 \mathrm{~mm} /$ year and reach $3000-5000 \mathrm{~mm} /$ year in the mountainous regions. Moreover, due to the effects of geography and typhoons, most of the rivers in Taiwan are intermittent rivers with steep slopes, great disparity in discharge, and high sediment transport rates. Hence, the management of watersheds in Taiwan is of vital importance. To successfully manage a watershed,

Keywords. Physiographic soil erosion-deposition model (PSED); spatially distributed soil erosion; suspended sediment transport rate; sediment yield. 
two main parameters, namely soil erosion and sediment yield, need to be accurately estimated and well controlled. Sediment transport rates can be calculated by multiplying flow discharge by sediment concentration, and then sediment yield can be obtained. Spatial distribution of soil erosion is an important reference to the design of hydraulic installation and the strategies of preventing serious erosion for soil conservation in watersheds.

Several empirical models are available to estimate the quantity of soil erosion such as Universal Soil Loss Equation (USLE) (Wischmeier and Smith 1978), Modified Universal Soil Loss Equation (MUSLE) (Williams 1975), and Revised Universal Soil Loss Equation (RUSLE) (Renard et al. 1991). These empirical models are popular because of their simple model structures and ease of use. Although these models are easy to use, they only describe the erosion processes for overland flow. Physically based simulation models can adequately calculate the quantity of runoff and effectively describe the movement of the solids. Popular physically based models are ANSWERS (Beasley et al. 1980), CREAMS (Knisel 1980), GUESS (Rose et al. 1983), EPIC (Williams et al. 1984), WEPP (Nearing et al. 1989), AGNPS (Young et al. 1989), GUEST (Misra and Rose 1990), and EUROSEM (Morgan et al. 1998). These models can simulate surface runoff and sediment transportation for independent precipitation events in a watershed using the law of conservation of mass and energy. However, these models require a large amount of hydrologic and physiographic parameters making them difficult to use in practice. For example, WEPP has 50 parameters (Brazier et al. 2000).

To handle numerous parameters, Geographic Information Systems (GIS) have been combined with rainfall-runoff models, sediment transportation models, and soil erosion models to calculate the surface runoff and sediment yield (Murakami et al. 2001; Sun et al. 2002; Wongsa et al. 2002; Paringit and Nadaoka 2003; Chen et al. 2004, 2006; Jain et al. 2005; Yuan et al. 2007). Even though the GIS can efficiently handle model parameters, the applicability and accuracy are limited to watersheds with simple parametric structure because these models will simplify the parametric structure. Bhattarai and Dutta (2007) linked GIS with USLE. Fu et al. (2006) and Ricker et al. (2008) linked GIS with RUSLE. They combined GIS with empirical models to efficiently estimate the total soil erosion and the erosion distribution of a watershed. These studies have a limited ability to estimate the erosion distribution within a watershed because they assume that all eroded soil will be brought to the outlet of the watershed.

In this study, a Physiographic Soil ErosionDeposition Model (PSED) is applied, which combines
GIS with physically based simulation models. This simulation model, which includes a physiographic rainfall-runoff model and a basin scale erosiondeposition model, can simulate the physical mechanism of the entire erosion process based on a detailed calculation of bed-load transport, surface soil entrainment, and deposition. With the assistance of GIS, the PSED model can handle enormous hydrologic and physiographic datasets and simulate the physical erosion process without the need for simplification. Accordingly, the proposed PSED model can provide detailed results including soil erosion quantities, erosion distribution, discharge hydrographs and suspended sediment transport rates at selected locations, and sediment yield. Chen et al. (2011) successfully applied the PSED model to simulate runoff and suspended sediment transport rate in a basin with multiple watersheds. A regression analysis conducted between measured flow discharge and sediment transport rate showed good agreement when compared to simulated results. Wu et al. (2012) estimated flow discharge, sediment concentration and consequently, sediment deposition volume into a $712.7 \times 10^{6} \mathrm{~m}^{3}$ capacity, Tseng-Wen reservoir, in Taiwan. Analysis of sixyear data revealed an observed sediment deposition of $32,020,000 \mathrm{~m}^{3}$ and PSED estimated deposition of $30,060,921 \mathrm{~m}^{3}$, indicating an acceptable $6 \%$ relative error.

The PSED model was applied to the Chou-Shui river basin, the longest river in Taiwan in the present study. The Chou-Shui river basin covers an area of $3155 \mathrm{~km}^{2}$ and contains 11 subwatersheds. Each watershed may have specific hydrologic and physiographic conditions and may be very different from adjacent watersheds. Accordingly, the characteristics of runoff and sediment transportation may differ spatially. We first verified the PSED model with three typhoon events by comparing simulated hydrographs with observed data. These three typhoons are Typhoon Herb (1996), Typhoon Zeb (1998) and Typhoon Nari (2001). We then verified the model with 40 rainfall events occurring in 2007. This verification was done by comparing simulated versus observed river discharge and sediment yield. This verification supports the accuracy of both; the model predicted suspended sediment transport rate and the model predicted sediment yield. Using this accurate erosion-deposition model, the basin-wide erosion and deposition distributions can be obtained.

\subsection{Physiographic soil erosion-deposition model (PSED)}

The PSED model uses GIS to define the area of each subwatershed based on the topography and the river network. The GIS then discretises 
each subwatershed into multiple computation cells which are classified into two categories: land cell and river cell (floodplains are classified to river cells). The hydrologic or physiographic attributive data are also calculated by using the analysis function embedded in the GIS. The PSED model then uses the computational cells along with the hydrologic and physiographic data in the rainfall-runoff model and erosion-deposition model.

\subsection{Rainfall-runoff model}

The rainfall-runoff model describes the water transportation process which begins with precipitation, becoming surface runoff, flowing throughout the entire basin, and finally arriving at the outlet of the basin. This transportation process can be calculated for each computation cell using the continuity equation (Chen et al. 2006):

$$
A_{i} \frac{\partial h_{i}}{\partial t}=\sum_{k} Q_{i, k}\left(h_{i}, h_{k}\right)+P_{e i}(t)
$$

where $t$ is time (sec); $A_{i}$ is the area $\left(\mathrm{m}^{2}\right)$ of the $i$ th cell; $h_{i}$ and $h_{k}$ are water levels $(\mathrm{m})$ of the $i$ th and $k$ th cells; $Q_{i, k}$ is the discharge $\left(\mathrm{m}^{3} / \mathrm{s}\right)$ flowing from the $i$ th cell to the adjacent $k$ th cell; and $P_{e i}$ is the effective precipitation volume per second $\left(\mathrm{m}^{3} / \mathrm{s}\right)$ in cell $i$ which can be obtained by multiplying the effective precipitation rate with the area of cell $i$.

The effective precipitation volume can be obtained using the following equation (Chow et al. 1988):

$$
\begin{gathered}
P^{\prime}=\frac{(P-0.2 S)^{2}}{(P+0.8 S)}, \\
S=25400 / C N-254,
\end{gathered}
$$

where $P$ is the depth of the total precipitation $(\mathrm{mm}) ; P^{\prime}$ is the depth of excess precipitation or direct runoff $(\mathrm{mm}) ; S$ is less than or equal to the potential maximum retention $(\mathrm{mm}) ; C N$ is the curve number which can be determined by land use and soil types.

If there is no flow barrier between two cells, the water flowing through the cell boundary can be calculated using Manning's equation. The discharge flowing from cell $k$ to cell $i$ can be expressed as follows:

$$
Q_{i, k}=\frac{h_{k}-h_{i}}{\left|h_{k}-h_{i}\right|} \cdot \Phi\left(\bar{h}_{i, k}\right) \cdot \sqrt{\left|h_{k}-h_{i}\right|} \quad \text { if } \frac{\partial Q_{i, k}}{\partial h_{i}} \leq 0
$$

$$
Q_{i, k}=\Phi\left(h_{k}\right) \cdot \sqrt{\left|h_{k}-h_{i}\right|} \quad \text { if } \frac{\partial Q_{i, k}}{\partial h_{i}}>0
$$

where $\bar{h}_{i, k}$ is the water level (m) of the boundary between cell $i$ and cell $k$; and $\Phi(h)$ is expressed as:

$$
\Phi(h)=\frac{\frac{1}{n} A_{w}(h) R^{2 / 3}(h)}{\sqrt{\Delta x}}
$$

where $\Delta x$ is the distance $(\mathrm{m})$ between the centroids of cell $i$ and cell $k ; n$ is the Manning's roughness coefficient between two cells; $A_{w}$ is the crosssectional flow area $\left(\mathrm{m}^{2}\right)$ between cell $i$ and cell $k$; and $R$ is the hydraulic radius $(\mathrm{m})$ between cell $i$ and cell $k$.

Flow barriers, such as roads, embankments, field ridges and banks are treated as broad crested weirs. Two flow barrier conditions may exist: free overfall weir and submerged weir. If the water level of cell $k$ is higher than the water level of cell $i\left(h_{k}>h_{i}\right)$, the discharge for two conditions can be described as follows:

(a) Free overfall weir $\left(h_{i}-h_{w}\right)<\frac{2}{3}\left(h_{k}-h_{w}\right)$ :

$$
Q_{i, k}=\mu_{1} B \sqrt{2 g}\left(h_{k}-h_{w}\right)^{3 / 2}
$$

(b) Submerged weir $\left(h_{i}-h_{w}\right) \geq \frac{2}{3}\left(h_{k}-h_{w}\right)$ :

$$
Q_{i, k}=\mu_{2} B \sqrt{2 g}\left(h_{i}-h_{w}\right)\left(h_{k}-h_{i}\right)^{1 / 2}
$$

where $h_{w}$ is the crest elevation (m) of the weir, which is the elevation of road surface, bank top, or ground surface at the boundary; $B$ is the length of the boundary $(\mathrm{m})$ between two adjacent cells; $g$ is the acceleration due to gravity $\left(\mathrm{m} / \mathrm{s}^{2}\right) ; \mu_{1}$ and $\mu_{2}$ are weir discharge coefficients for free overfall weir and submerged weir, respectively. Tsai and Tsai (1997) suggested that $\mu_{1}=0.36 \sim 0.57$ and $\mu_{2}=2.6 \mu_{1}$. In this study, we adopted $\mu_{1}=0.47$ and $\mu_{2}=1.22$.

Applying the explicit finite difference scheme, equation (1) for cell $i$ can be expressed as follows:

$$
h_{i}^{m+1}=h_{i}^{m}+\frac{\left(\sum_{k} Q_{i, k}^{m}+P_{e i}^{m}\right)}{A_{i}} \cdot \Delta t
$$

where the superscript $m$ denotes the time index, $t_{m}$ (sec); $h_{i}^{m+1}$ represents the water level of cell $i$ at time $t_{m+1}(\mathrm{sec})$; and $\Delta t$ is the time increment (sec) between $t_{m}$ and $t_{m+1}$. The relationship between $Q_{i, k}$ and $h_{i}$ and $h_{k}$ may be derived from equations (4), (5), (7), or (8). Equation (9) provides the elevation of water surface. These equations are then used in conjunction with GIS, which handles the hydrologic and physiographic data, to calculate hydrographs of the water levels for each cell. 
The water depth in the $i$ th cell can be obtained as follows:

$$
D_{i}=h_{i}-z_{i}
$$

where $D$ is the depth $(\mathrm{m})$ of the flow; $z$ is the elevation $(\mathrm{m})$ of the ground surface or channel bed.

\subsection{Soil erosion-deposition model}

To simulate the erosion and deposition processes, the soil erosion-deposition model calculates the sediment transport rate and bed variation based on the bed load transport rate formula and the continuity equations of suspended sediment and bed load (Chen et al. 2006):

$$
\begin{gathered}
\frac{\partial V_{s i}}{\partial t}=\sum_{k} Q_{S C_{i, k}}+Q_{s e i}-Q_{s d i}+R_{D T i} \\
(1-\lambda) \frac{\partial V_{d i}}{\partial t}=\sum_{k} Q_{S B_{i, k}}-Q_{s e i}+Q_{s d i}-R_{D T i}
\end{gathered}
$$

where $V_{s i}$ is the volume $\left(\mathrm{m}^{3}\right)$ of suspended sediment in cell $i\left(V_{s i}=A_{i} \times D_{i} \times C_{i}\right) ; C$ is the volumetric concentration of suspended sediment; $\lambda$ is the porosity; $V_{d i}$ is the volume $\left(\mathrm{m}^{3}\right)$ of the deposition layer in cell $i ; Q_{S C_{i, k}}$ and $Q_{S B_{i, k}}$ are transport rates $\left(\mathrm{m}^{3} / \mathrm{s}\right)$ of suspended sediment and bed load, respectively, from cell $k$ to adjacent cell $i ; Q_{\text {sei }}$ is the entrained rate $\left(\mathrm{m}^{3} / \mathrm{s}\right)$ of ground surface soil if cell $i$ is a land cell, or the entrained rate of river bed sediment if cell $i$ is a river cell; $Q_{s d i}$ is the deposition rate $\left(\mathrm{m}^{3} / \mathrm{s}\right)$ of cell $i$; and $R_{D T i}$ is the rainfall detachment rate $\left(\mathrm{m}^{3} / \mathrm{s}\right)$ of cell $i$.

The entrained rate per unit area, $q_{s e}(\mathrm{~m} / \mathrm{s})$, and deposition rate, $q_{s d}(\mathrm{~m} / \mathrm{s})$, can be expressed as follows (Itakura and Kishi 1980):

$$
\begin{gathered}
q_{s e}=0.008 \sqrt{s g d}\left[0.14 \frac{\rho}{\rho_{s}}\left(14 \sqrt{\tau_{*}}-\frac{0.9}{\sqrt{\tau_{*}}}\right)-\frac{\omega_{s}}{\sqrt{s g d}}\right] \\
q_{s d}=\omega_{s} C_{b}
\end{gathered}
$$

where $s=\left(\rho_{s}-\rho\right) / \rho$ is the effective density coefficient; $\rho_{s}$ and $\rho$ are density $\left(\mathrm{kg} / \mathrm{m}^{3}\right)$ of the sediment and clear water, respectively; $d$ is the diameter $(\mathrm{m})$ of sediment; $\omega_{s}$ is the fall velocity $(\mathrm{m} / \mathrm{s})$ of the sediment; $\tau_{*}$ is dimensionless bed shear stress $\left(=u_{*}^{2} / s g d\right) ; u_{*}$ is the shear velocity $(\mathrm{m} / \mathrm{s})$; and $C_{b}$ is the volumetric concentration of suspended sediment close to the bed. Shimizu et al. (1990) suggested that this concentration can be approximated as the suspended sediment concentration at $5 \%$ depth from the channel bed.

$$
C_{b}=\frac{P_{e}}{\left[1-\exp \left(-P_{e}\right)\right]} C
$$

where $P_{e}$ is the Peclet number which can be expressed as $\omega_{s} D / \varepsilon$; $\varepsilon$ is the eddy viscosity factor $\left(\kappa u_{*} D / 6\right)$; and $\kappa$ is the von Karman constant which is assigned a value of 0.4 in this study. The volumes of entrained sediment and deposited sediment per unit time in the $i$ th cell can be expressed as follows:

$$
\begin{gathered}
Q_{s e i}=q_{s e} \cdot A_{i} \cdot c^{\prime} \quad(\text { if cell } i \text { is a land cell }) \\
Q_{s e i}=q_{s e} \cdot A_{i} \quad(\text { if cell } i \text { is a river cell }) \\
Q_{s d i}=q_{s d} \cdot A_{i}
\end{gathered}
$$

where $c^{\prime}$ is the coverage factor which is related to land use type.

Sediment enters the state of motion as the shear stress exerted on the bed material exceeds the critical shear stress. In this study, the equation to calculate the bed load transport rate as follows (Chen et al. 2004, 2006):

$\gamma D S_{f}=0.047\left(\gamma_{s}-\gamma\right) d+0.25\left(\frac{\gamma}{g}\right)^{1 / 3}\left(\frac{\gamma_{s}-\gamma}{\gamma_{s}}\right)^{2 / 3} q_{b}^{2 / 3}$

where $S_{f}$ is the friction slope; $\gamma_{s}$ and $\gamma$ are specific weight $\left(\mathrm{kgw} / \mathrm{m}^{3}\right)$ of sediment and clear water, respectively; $q_{b}$ is the bed load transport rate per unit bed width $\left(\mathrm{m}^{2} / \mathrm{s}\right)$. The discharge of bed load, $Q_{S B_{i, k}}$, can be expressed as follows:

$$
\begin{gathered}
Q_{S B_{i, k}}=q_{b_{i, k}} \cdot B \cdot c^{\prime} \quad(\text { if cell } i \text { is a land cell }) \\
Q_{S B_{i, k}}=q_{b_{i, k}} \cdot B \quad(\text { if cell } i \text { is a river cell })
\end{gathered}
$$

Rainfall leads to soil detachment, resulting in soil erosion. The erosion process is strongly affected by the soil type, vegetation, and water depth on the soil surface. When the water depth is larger than three times the raindrop diameter, rain drops are considered to have no impact on the soil. Under this condition, the detachment rate is considered to be zero (Mutchler and Young 1975). The raindrop diameter is correlated with the rainfall intensity as follows (Ma 1995):

$$
d_{50}=1.56 I^{0.096}
$$

where $d_{50}$ is the median diameter of the raindrops $(\mathrm{mm})$; and $I$ is the rainfall intensity $(\mathrm{mm} / \mathrm{hr})$. The detachment rate can be expressed as follows:

$$
\begin{aligned}
& R_{D T i}=a \cdot I^{b} \cdot A_{i} \quad \text { if } D \leq 3 d_{50} \\
& R_{D T i}=0 \quad \text { if } D>3 d_{50}
\end{aligned}
$$

where $a$ and $b$ are calibrated parameters. Hu et al. (1995) suggested that $a$ should range from 18.36 to 
21.72 and $b$ should range from 0.81 to 1.29 . In this study, $a$ is 20 and $b$ is 1.0 .

Applying the explicit finite difference scheme, equation (11) can be expressed as follows:

$$
C_{i}^{m+1}=\frac{\left(\sum_{k} Q_{S C_{i, k}}^{m}+Q_{s e i}^{m}-Q_{s d i}^{m}+R_{D T i}^{m}\right)}{A_{i} D_{i}^{m+1}} \cdot \Delta t
$$

The discharge of suspended sediment between two cells $\left(Q_{S C_{i, k}}\right)$ is calculated based on the flow direction of $Q_{i, k}$. If the flow direction is from cell $k$ to cell $i, Q_{S C_{i, k}}=\left|Q_{i, k}\right| \times C_{k}$. On the other hand, if the flow direction is from cell $i$ to cell $k$, $Q_{S C_{i, k}}=-\left|Q_{i, k}\right| \times C_{i}$. In equation (22), $Q_{\text {sei }}, Q_{s d i}$, and $R_{D T i}$ can be obtained from equations (16), (17), and (22), respectively. $D_{i}$ can be calculated using equation (10).
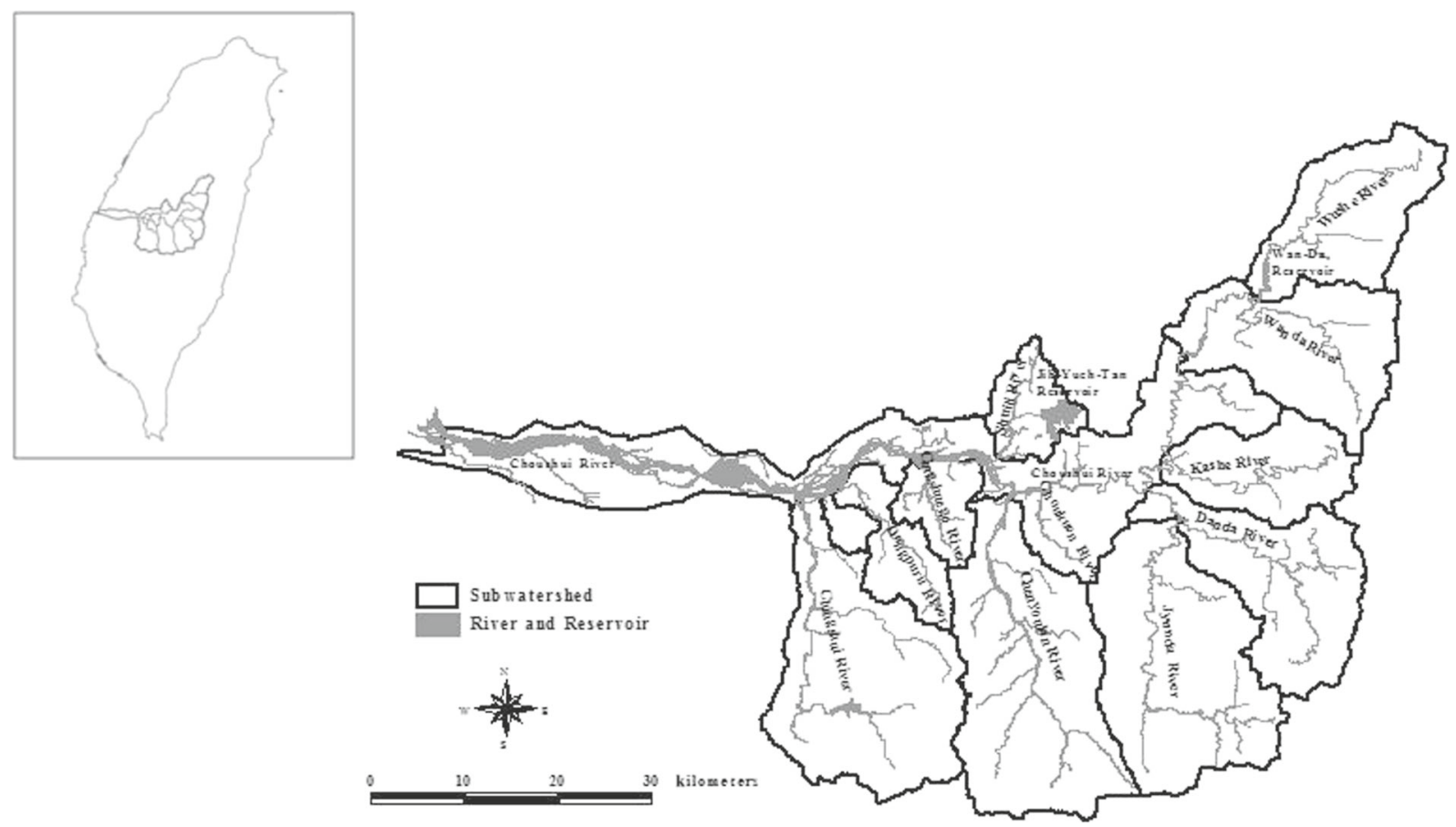

Figure 1. Chou-Shui river basin with 11 subcatchments.

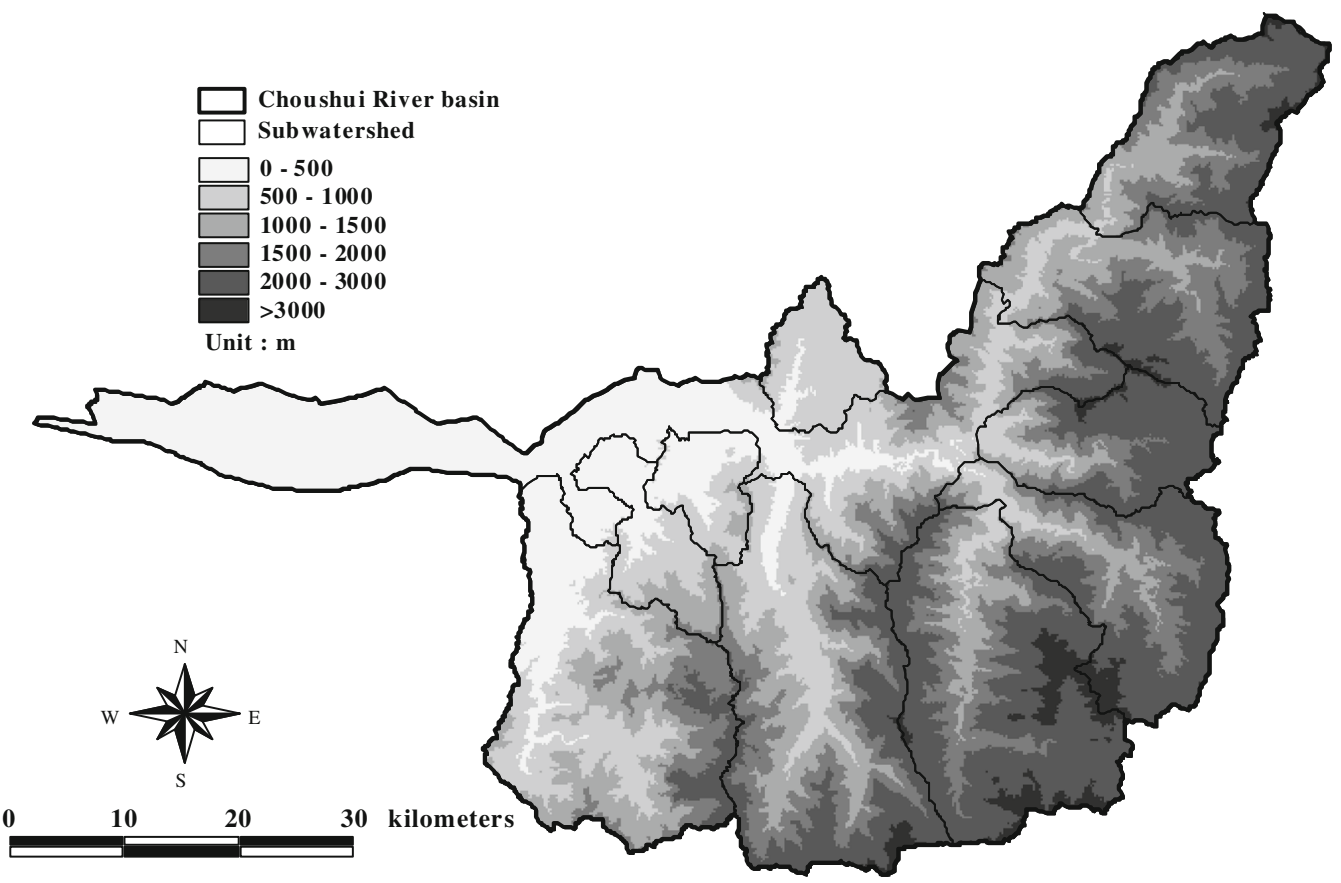

Figure 2. Digital elevation map (DEM) of Chou-Shui river basin. 
Similarly, equation (12) can be expressed as:

$\Delta z_{i}=\frac{\left(\sum_{k} Q_{S B_{i, k}}^{m}+Q_{s e i}^{m}-Q_{s d i}^{m}-R_{D T i}^{m}\right)}{A_{i}(1-\lambda)} \cdot \Delta t$

$$
z_{i}^{m+1}=z_{i}^{m}+\Delta z_{i}
$$

where $\Delta z_{i}$ is the variation in bed elevation $(\mathrm{m})$ in cell $i$ (a positive value represents deposition and a negative value represents erosion). The bed load discharge $\left(Q_{S B_{i, k}}\right)$ between two adjacent cells is determined by the direction of $Q_{i, k}$ using equation (19). The value of $Q_{S B_{i, k}}$ is positive if the discharge flows into cell $i$ and negative if it flows out from cell $i$.

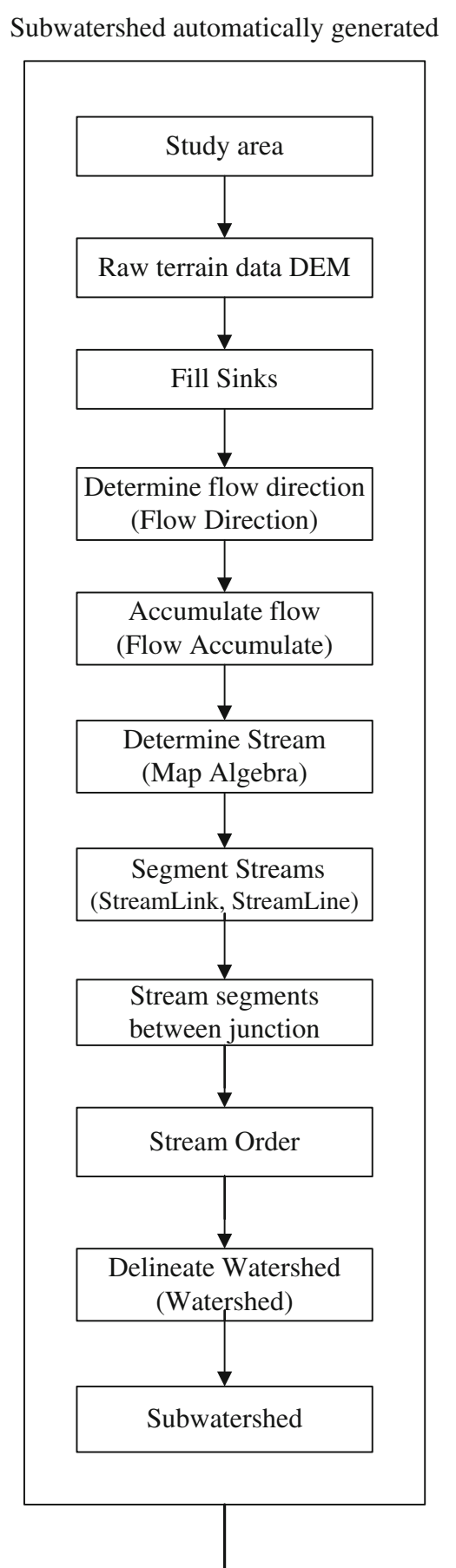

Computed cells generated

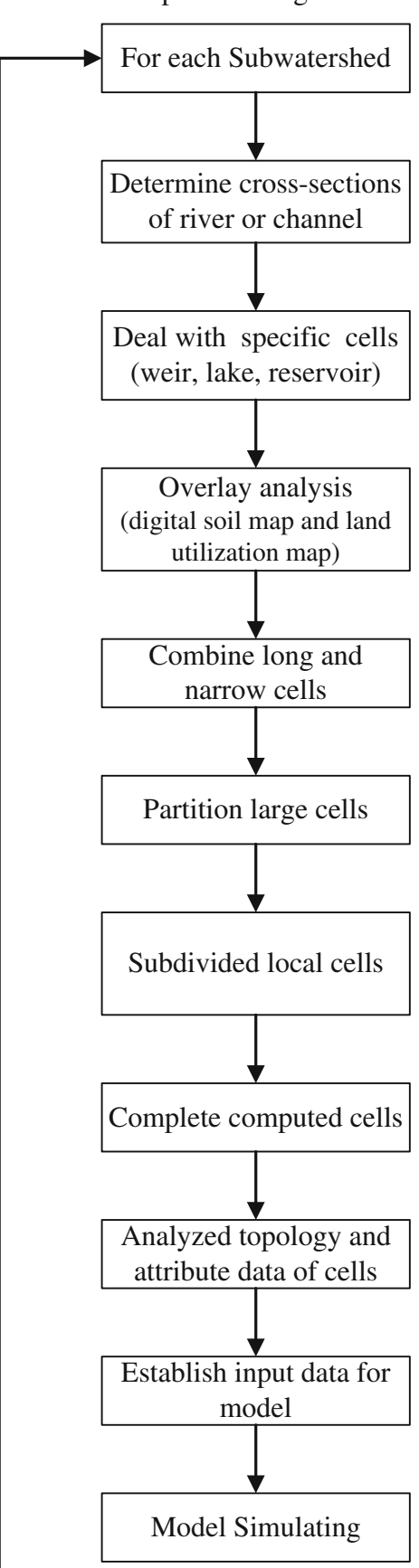

Figure 3. Flowchart describing the procedure for the generation of the computational cells. 


\section{Study area: Chou-Shui river basin, Taiwan}

The Chou-Shui river basin is located in the central western region of Taiwan with a watershed area of $3155 \mathrm{~km}^{2}$. The Chou-Shui River is the longest river in Taiwan (186.4 km in length). Due to significant erosion problems resulting from the river's geographic characteristics and a steep main channel slope, the Chou-Shui River is also known for its high turbidity. The river's source elevation is $3200 \mathrm{~m}$ above sea level (asl) and the average channel bed slope is $1.72 \%$. Before the river flows west into the Taiwan Strait, it collects water from 11 subwatersheds: Wushe, Wanda, Kashe, Danda, Chunda, Chenyoulan, Chingshui, Donpuru, Chingshuigo, Shuili, and Chou-Shui river watersheds (figure 1).

\subsection{Application of GIS}

Due to the variation in topography, landform, vegetation, and land use in the basin, the runoff process caused by rainfall and the induced erosion may be different spatially. Therefore, for the determination of runoff process and the quantity of sediment yield and soil erosion in the basin, the computational cells are divided according to the topography and landform. The Chou-Shui river basin has 11 subwatersheds with different landforms, vegetations, soil types, and land uses. The complexity in the topography results in extremely large hydrologic and physiographic datasets. These datasets are handled by ArcGIS ${ }^{\mathrm{TM}}$ (ArcView ${ }^{\circledR}$ and Arc/Info ${ }^{\circledR}$, extension modules (spatial analysis, hydrologic model, 3D Analyst, Network Analyst), and the Object-Oriented Programming Language (Avenue). This data consists of slope, area, average elevation, roughness, $C N$ value, etc. In addition, GIS can also determine the flow direction, the accumulated discharge, the main river channel geometries, and the ridge locations between any two subwatersheds.

\subsection{Spatial discretisation}

The Chou-Shui river basin is divided into 11 subwatersheds based on the topographic data. The topography characteristics are identified using a digital elevation model (DEM), as shown in figure 2. The digital topographic information in Taiwan is mostly obtained from aerial mapping photography now. The resolution of the topographic information is $5 \mathrm{~m} \times 5 \mathrm{~m}$ in a regular cell.

In the basin, each subwatershed delineation consists of two clusters of cells. One represents the river cells, and the other represents the land cells, which is superimposed upon layers such as soil types, land uses, and road buffers. Refinement may be needed to either regroup fine cells to a coarse one or fine tune coarse cell into a group of fine cells.

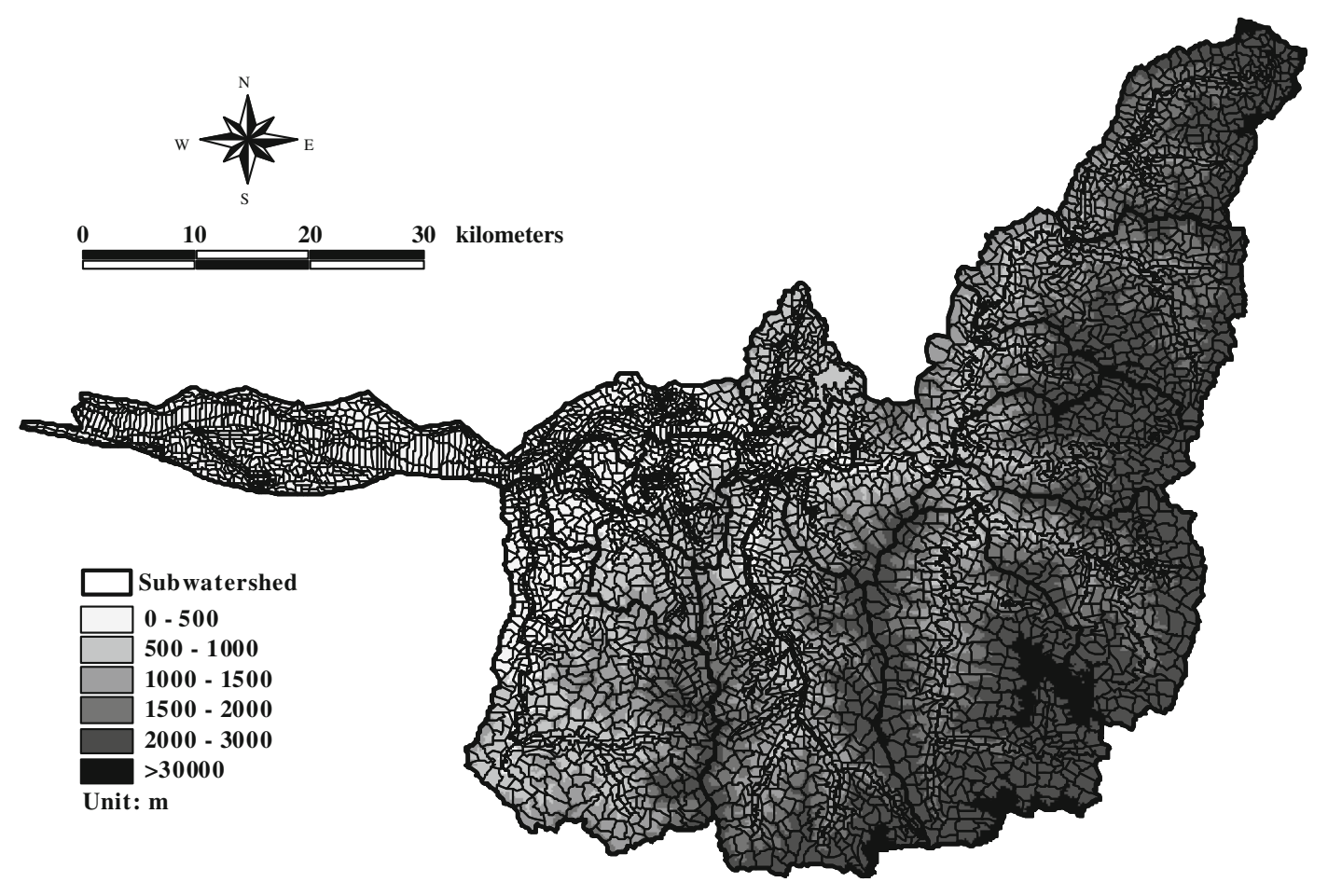

Figure 4. Computational cells of Chou-Shui river basin. 
Figure 3 describes the method and procedure of the generation of the computational cells. The resulting Chou-Shui river basin model contains 6421 cells (figure 4).

\subsection{Hydrologic and physiographic data}

To collect hydrologic data, there are 34 rain gauges and 10 hydrologic stations in the study area (figure 5).
Because the rain gauges are not uniformly distributed, the Thiessen polygon method was applied to determine the aerial extent represented by each rain gauge (figure 5). The Taiwan Water Resources Agency (TWRA), measures river discharge and suspended sediments as part of river management from the hydrological stations. DH-59 and Price flow meter are employed to measure the suspended sediments and flow velocity, respectively. The

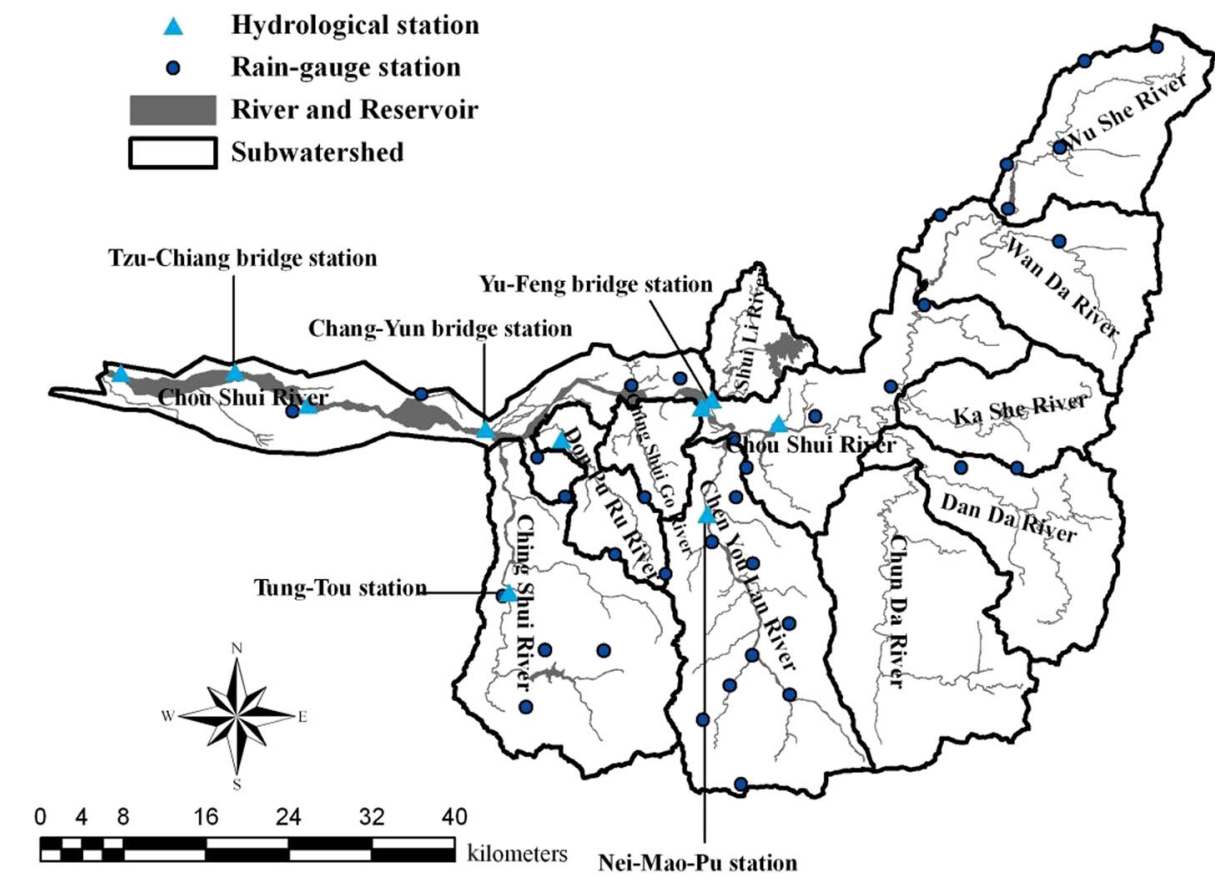

Figure 5. Locations of rain gauges, hydrologic stations and rain gauge control areas in the Chou-Shui river basin.

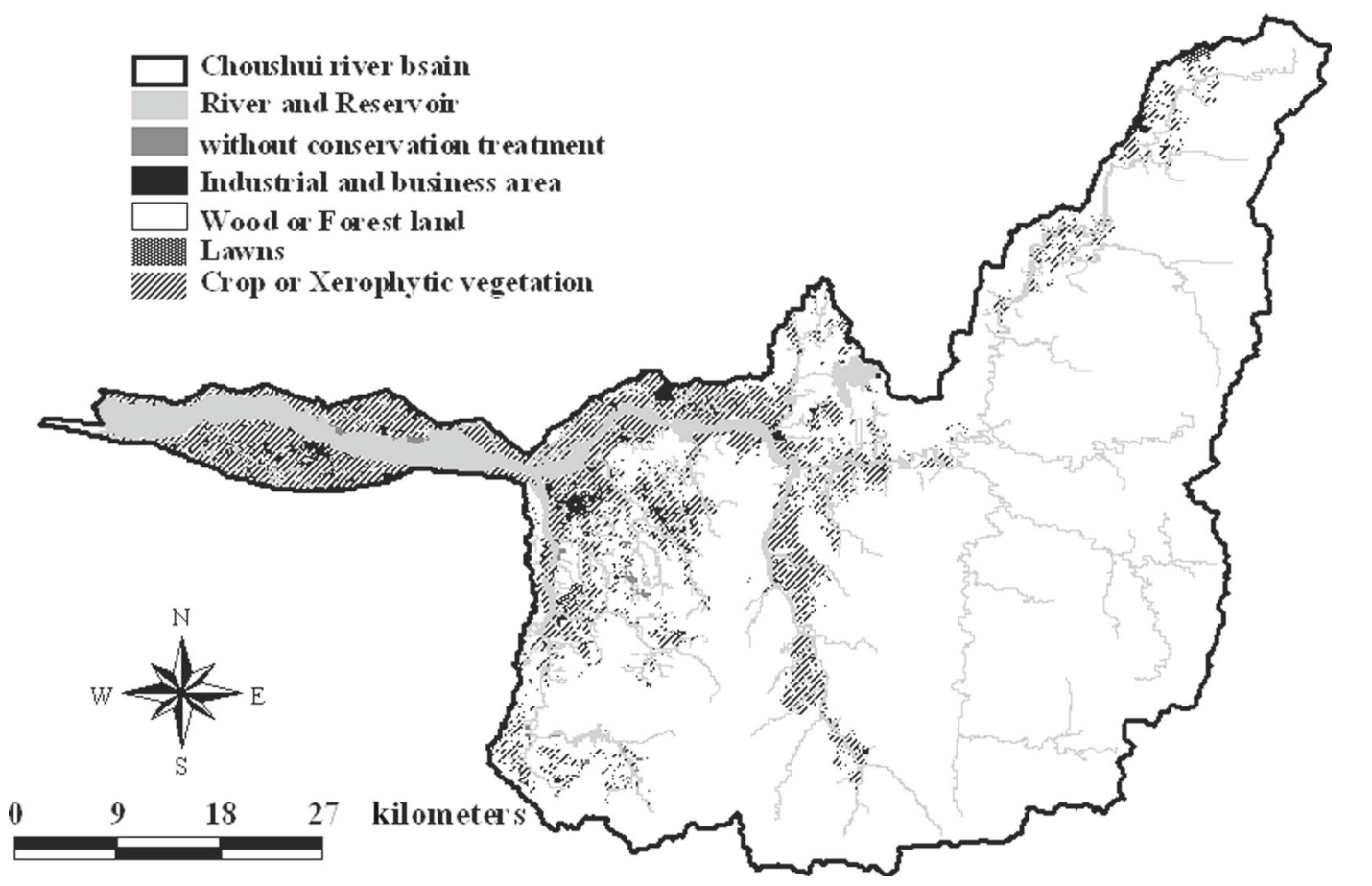

Figure 6. Land uses of Chou-Shui river basin. 
operation and descriptions of this equipment are given by Edwards and Glysson (1999). The TWRA employs the mid-section method of measurement (Wang et al. 2013). This method assumes that the velocity samples at each depth sampling point (or vertical) represent the mean velocity in a particular rectangular cross-sectional area. The total depth of a vertical determined the measurement depths of velocity. If depths were $<75 \mathrm{~cm}$, measurements were taken at 0.6 depths of that vertical. If depths were $>75 \mathrm{~cm}$, measurements were taken at 0.2 and

Table 1. Manning's roughness coefficients and coverage factors for various land uses (Chen et al. 2004).

\begin{tabular}{lcc}
\hline Land uses & $\begin{array}{c}\text { Manning's } \\
\text { roughness } n\end{array}$ & $\begin{array}{r}\text { Crop management } \\
\text { factor } c^{\prime}\end{array}$ \\
\hline Meadow & 0.35 & 0.15 \\
Lawns & 0.25 & 0.05 \\
Without conservation & 0.20 & 1.00 \\
$\quad$ treatment & 0.035 & 0.00 \\
River and reservoir & 0.10 & 0.10 \\
Paddy field & 0.35 & 0.25 \\
Crop or xerophytic & & 0.20 \\
$\quad$ vegetation & 0.40 & 0.01 \\
Orchard & 0.45 & 0.01 \\
Wood or forest land & 0.35 & 0.01 \\
Bush & 0.10 & \\
Industrial and & & \\
business area & & \\
\hline
\end{tabular}

0.8 of depths, and averages of these were used. The summation of the product of velocity and each cross-sectional area gave the total discharge for that particular stream, a method referred as the velocity area method (Edwards and Glysson 1999). Water samples (0.5 litres) for suspended sediment concentration (SSC) measurements were collected at each vertical where velocity measurements were taken using the depth integrating sampler (DH-59). Suspended sediment concentrations were measured using the evaporation method as outlined by ASTM D3977 (2007). To calculate sediment discharge, water discharge is multiplied by SSC. Precipitation data is used as input for the simulation model. The river discharge and concentration data are used for model calibration and verification.

To incorporate the physiographic data, we had to calculate the geometric properties of each cell, such as slope, area, and average elevation, by overlaying the DEM (figure 2) with the cell map (figure 4). In addition, we also used GIS to handle land use and vegetation data which determine the value of Manning's roughness coefficient in the rainfall-runoff model as well as the bed load transport rate and suspended transport rate in the soil erosiondeposition model. Figure 6 shows the land use of the Chou-Shui river basin and table 1 lists the values of Manning's roughness coefficient and coverage factor for each type of vegetation and land use, respectively. Similarly, the physiographic properties of the land use and vegetation of each cell

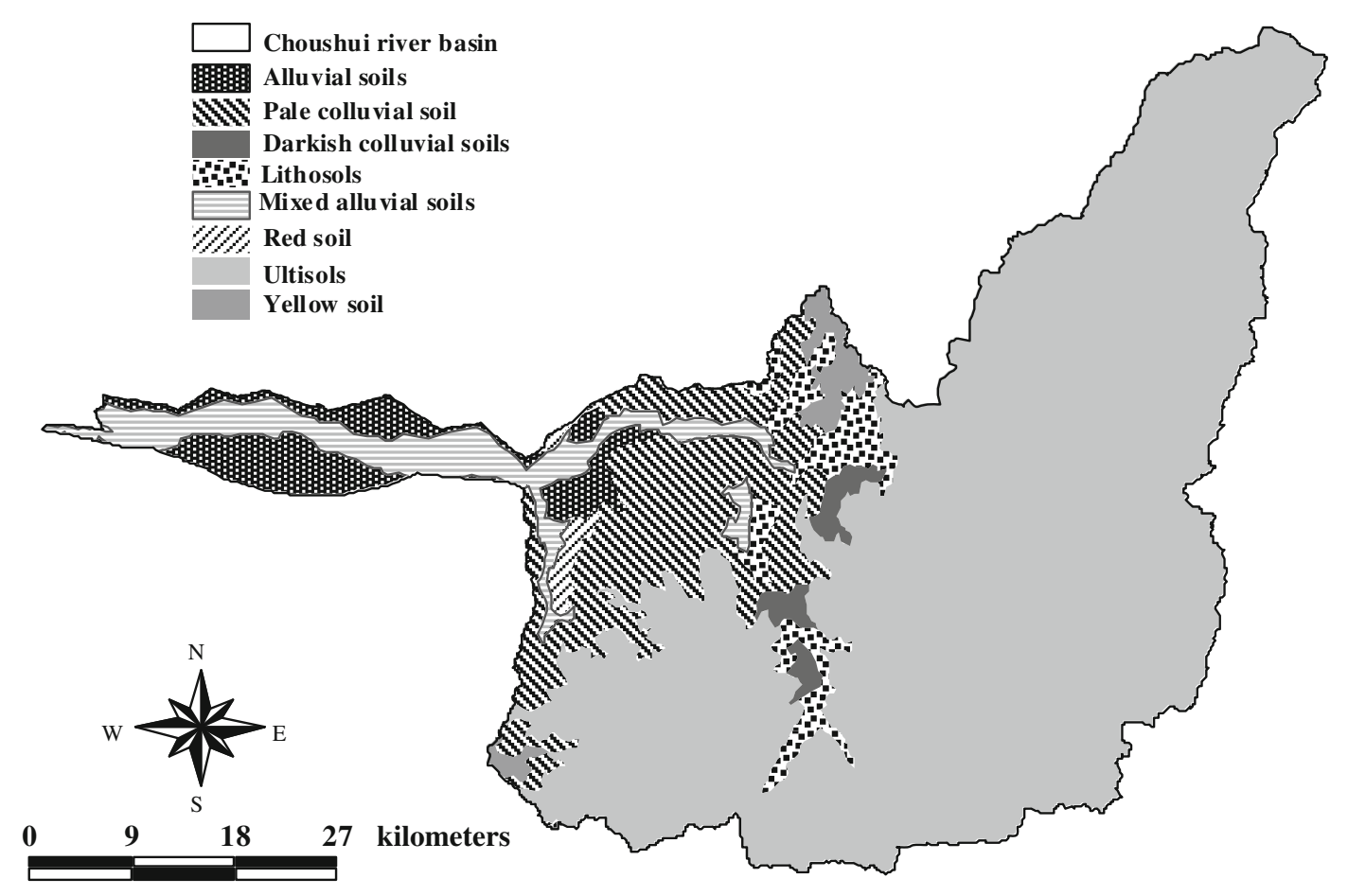

Figure 7. Soil type distribution of the Chou-Shui river basin. 

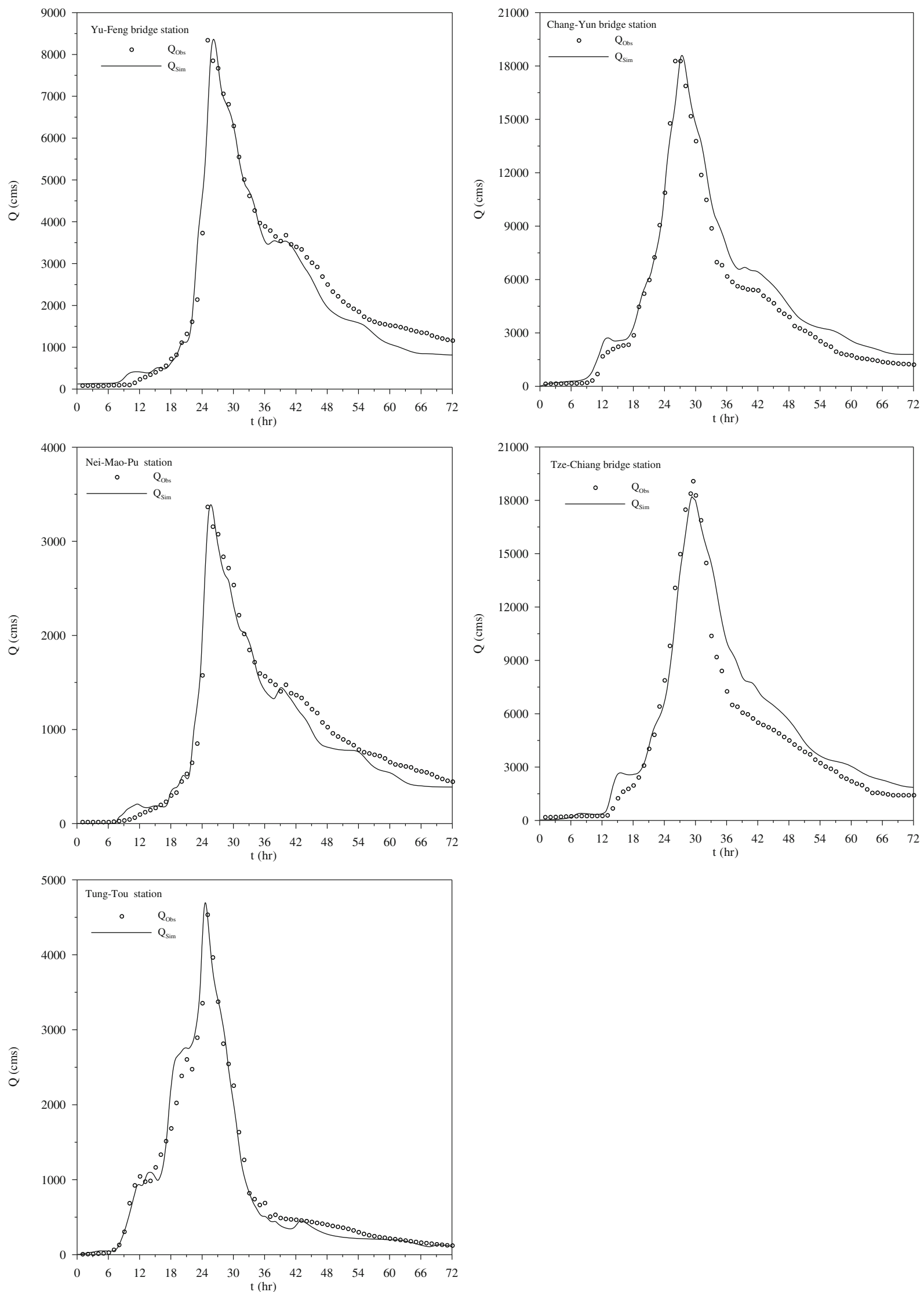

Figure 8. The comparison between simulated and observed flow discharge ( $\mathrm{cms}-$ cubic metres per second) at hydrologic stations during Typhoon Herb. 
were obtained by overlaying the land use map with the cell map. Using these physiographic properties and table 1, we obtained the Manning's roughness coefficient and the coverage factor for each cell. Figure 7 shows the soil type distribution for the study area based on soil classification by Sheh and Wang (1991). Additionally, upon overlaying the soil map with the cell map, the representative soil particle diameter was obtained for each cell. The representative diameter of soil particles in river cells is based on measured data.

\subsection{Calculation procedures of GIS and PSED model}

The procedures used to calculate water depth, volumetric concentration of suspended sediment, and
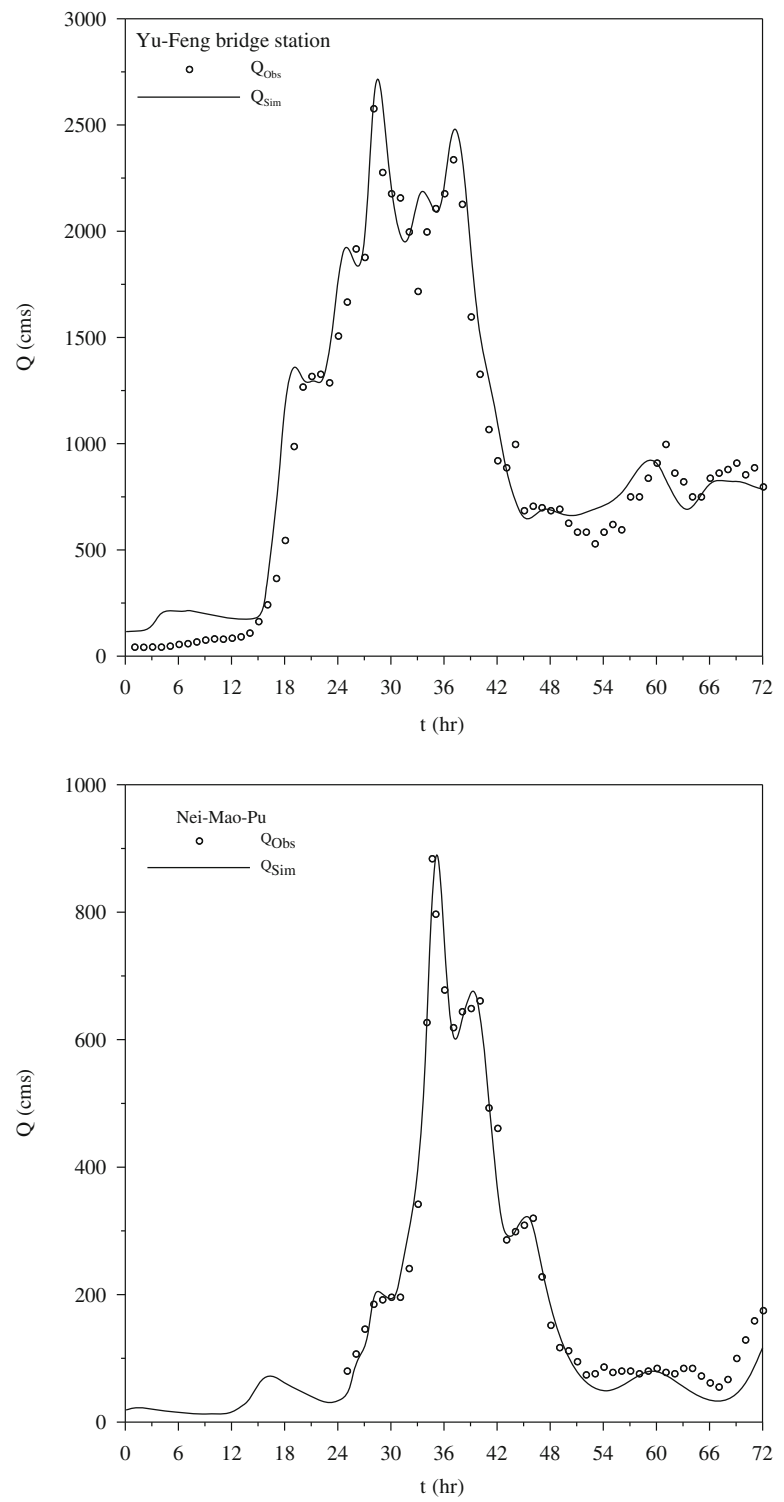

bed variation using the proposed PSED model, in conjunction with GIS, are as follows:

- Use GIS to define subwatersheds. Each subwatershed is further partitioned into multiple cells based on the appropriate resolution. These cells are characterized as land cells or river cells based on their properties.

- Use GIS to analyze the hydrologic and physiographic data including precipitation, vegetation, land uses, geometry, topology, elevation, weir coefficients, particle diameters, and initial conditions. The necessary parameters are then calibrated and the results are saved in the database.

- Prepare the input files for the PSED model using the database from step 2.
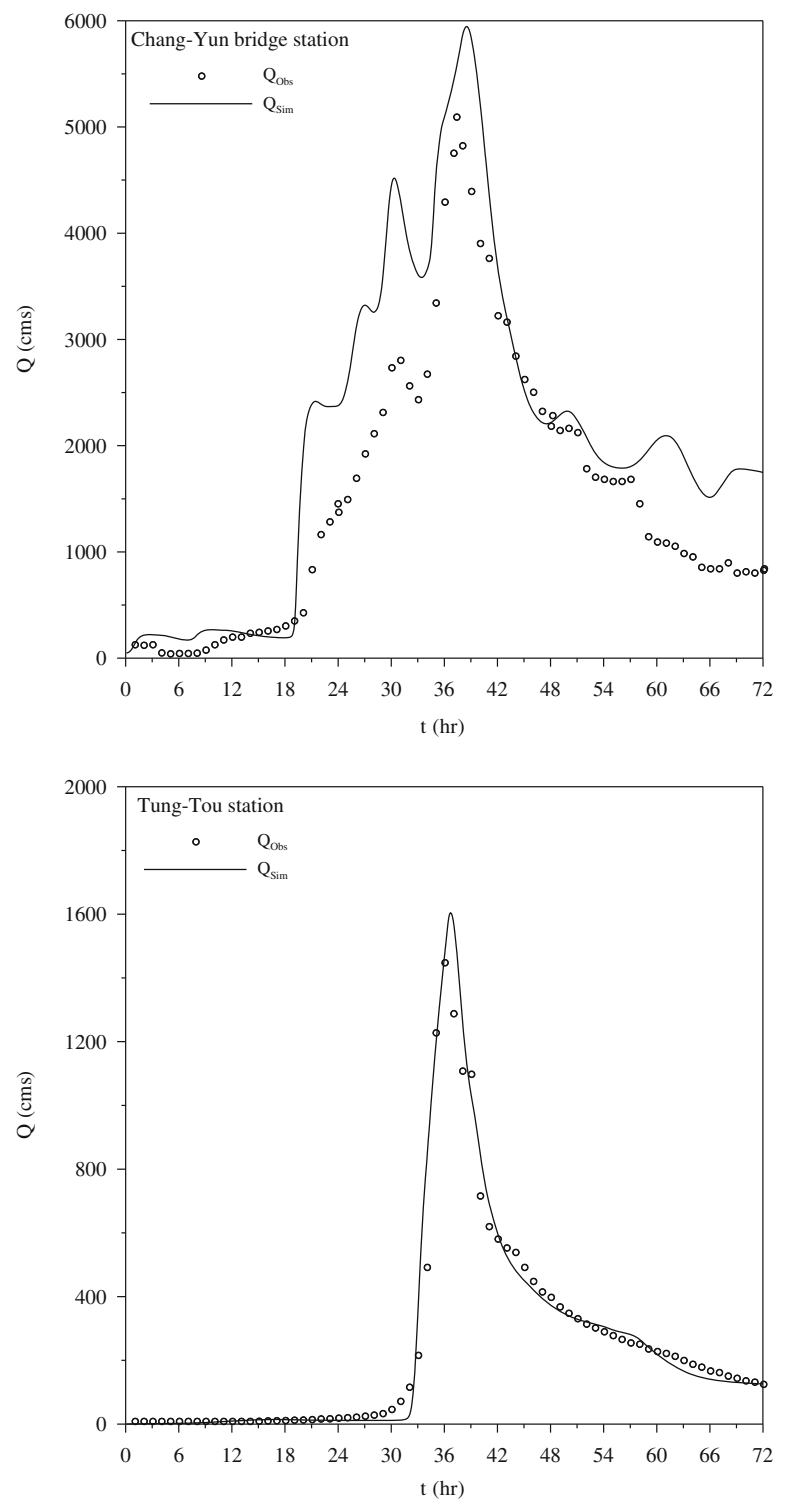

Figure 9. The comparison between simulated and observed flow discharge at hydrologic stations during Typhoon Zeb (observed flow discharge data at the Tzu-Chiang bridge station was not available). 
- Calculate the overland flow using equations (9) and (10) to obtain the water depth in each cell. $\Delta t=1.0 \mathrm{sec}$.

- Simulate soil erosion and deposition to obtain the volumetric concentration of suspended sediment, bed variation, and bed elevation of each cell using equations (22), (23), and (24), respectively.

- Repeat step 4 using the bed elevation obtained from step 5. Repeat step 6 until the end of the rainfall event.

\section{Results and discussion}

To verify the proposed PSED model, we used three typhoon events to verify the rainfall-runoff model and used a total of 40 rainfall events in 2007, including two typhoon events, to verify the soil
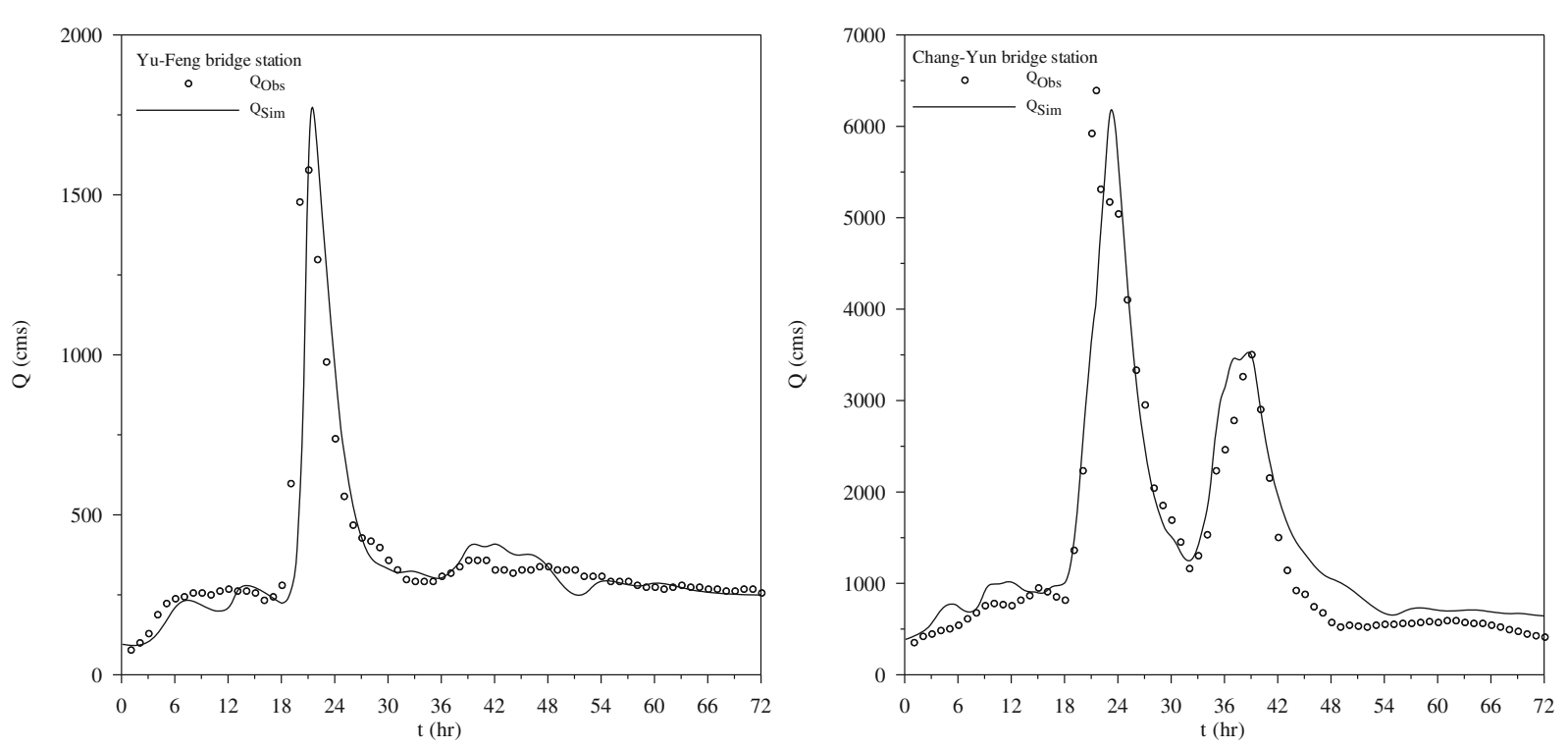

erosion-deposition model. First, we compared the simulated river discharge with the discharge measurements from the typhoon events, Typhoon Herb in 1996 (which is about 100-year return period rainfall event), Typhoon Zeb in 1998, and Typhoon Nari in 2001. These events were chosen because of the abundance of observation data taken during each event. Then, we compared the model predicted relationship between discharge and suspended sediment transport rate of each storm event with that which was obtained from the measured data using regression analysis.

\subsection{Comparisons between simulated and measured discharge hydrographs}

Due to the relative abundance of observed data, we compared the simulated discharge hydrographs

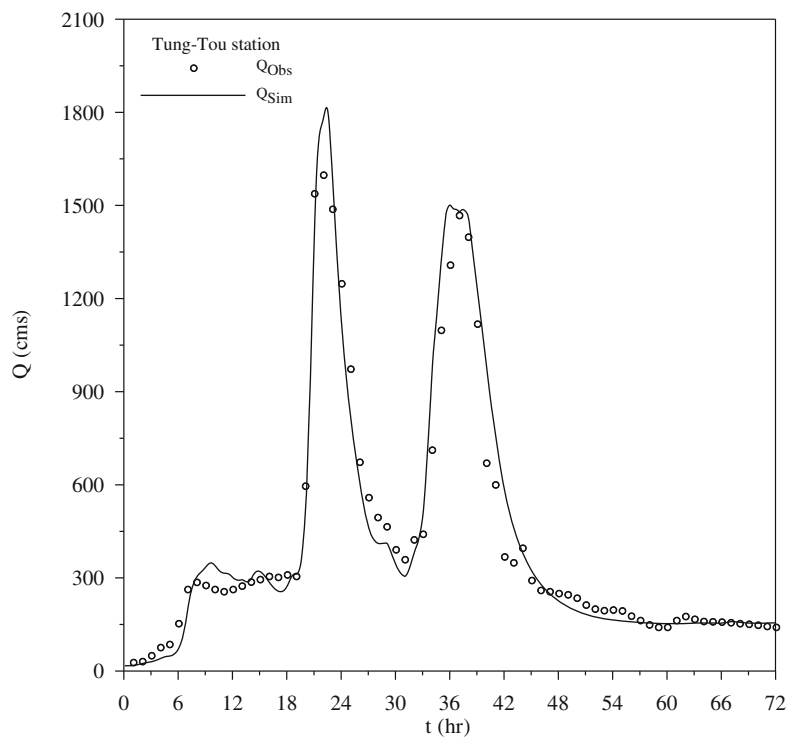

Figure 10. The comparison between simulated and observed flow discharge at hydrologic stations for Typhoon Nari (observed flow discharge data at the Nei-Mao-Pu and Tzu-Chiang bridge stations were not available). 


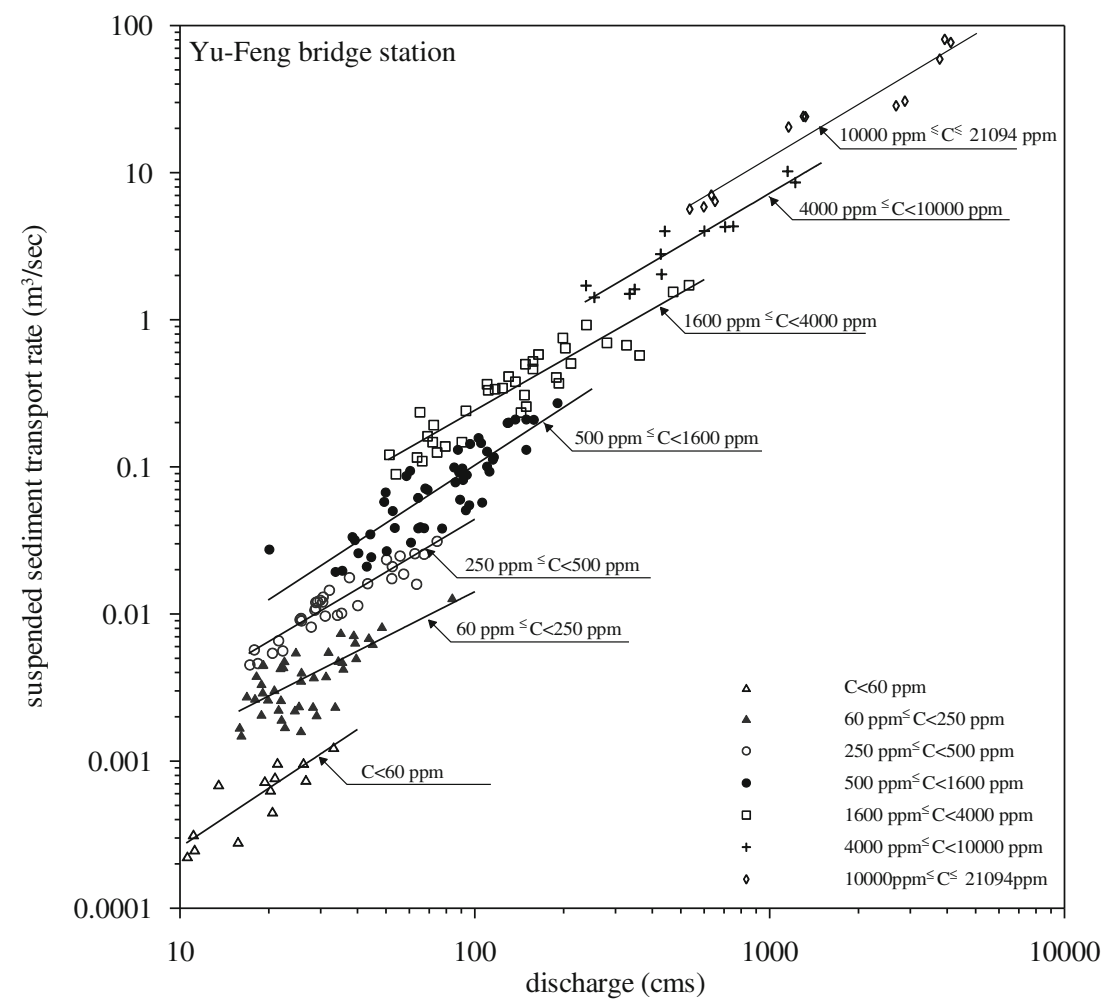

Figure 11. Observed relationship between flow discharge and sediment transport rate at Yu-Feng bridge station.

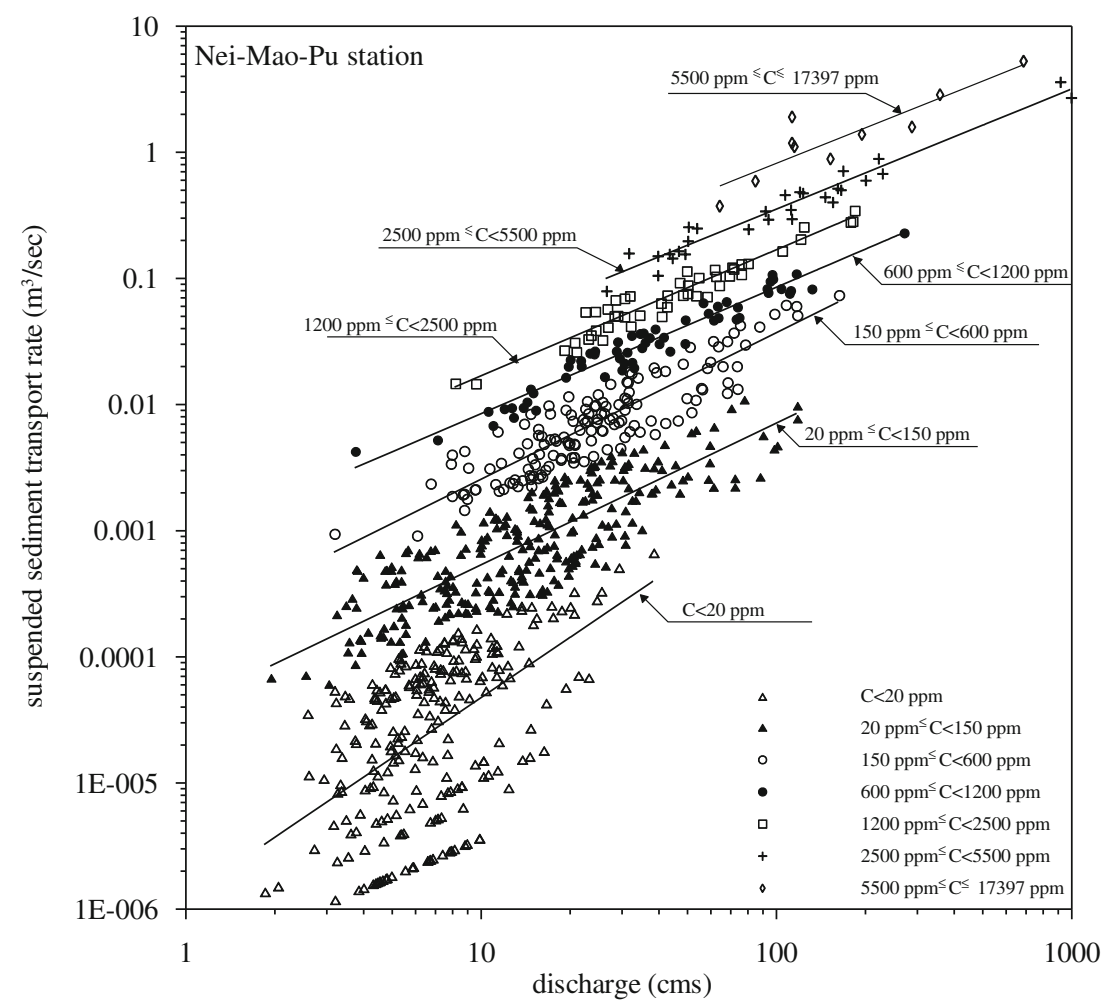

Figure 12. Observed relationship between flow discharge and sediment transport rate at Nei-Mao-Pu station. 


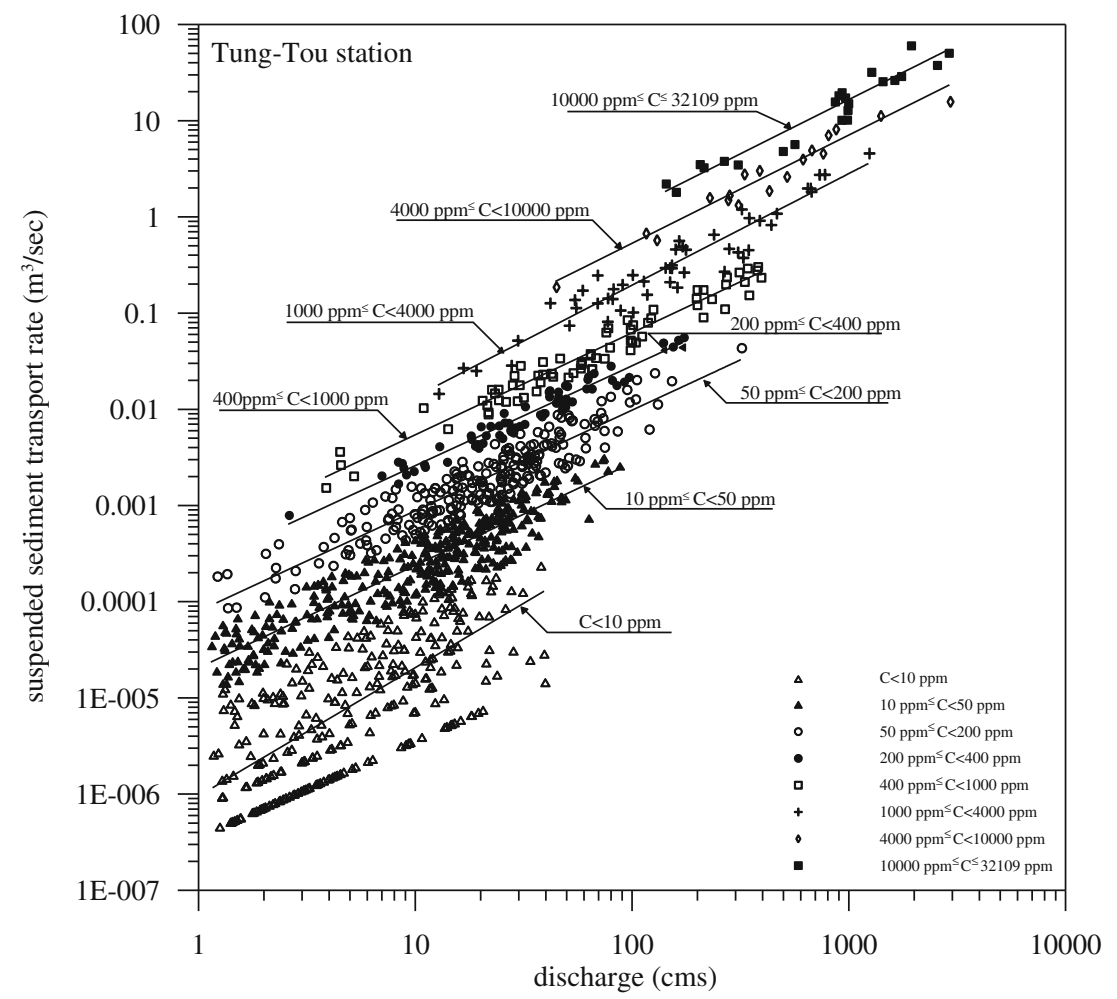

Figure 13. Observed relationship between flow discharge and sediment transport rate at Tung-Tou station.

Table 2. Relationship between flow discharge and sediment transport rate at Yu-Feng bridge station.

\begin{tabular}{|c|c|c|c|}
\hline $\begin{array}{l}\text { Suspended sediment } \\
\text { volumetric concentration } \\
(\mathrm{ppm})\end{array}$ & Regression equation & & $\begin{array}{c}\text { Correlation } \\
\text { coefficient }\end{array}$ \\
\hline$C<60$ & $Q_{s}=1.1294 \times 10^{-5} \times Q^{1.3291}$ & $(25.1)$ & $R^{2}=0.7303$ \\
\hline $60 \leq C<250$ & $Q_{s}=1.3317 \times 10^{-4} \times Q^{1.0136}$ & $(25.2)$ & $R^{2}=0.5074$ \\
\hline $250 \leq C<500$ & $Q_{s}=1.8359 \times 10^{-4} \times Q^{1.1901}$ & $(25.3)$ & $R^{2}=0.8784$ \\
\hline $500 \leq C<1600$ & $Q_{s}=2.5017 \times 10^{-4} \times Q^{1.3065}$ & $(25.4)$ & $R^{2}=0.7529$ \\
\hline $1600 \leq C<4000$ & $Q_{s}=1.2609 \times 10^{-3} \times Q^{1.1421}$ & $(25.5)$ & $R^{2}=0.8625$ \\
\hline $4000 \leq C<10000$ & $Q_{s}=2.1040 \times 10^{-3} \times Q^{1.1790}$ & $(25.6)$ & $R^{2}=0.8985$ \\
\hline $10000 \leq C \leq 21094$ & $Q_{s}=2.2257 \times 10^{-3} \times Q^{1.2021}$ & $(25.7)$ & $R^{2}=0.9356$ \\
\hline
\end{tabular}

Table 3. Relationship between flow discharge and sediment transport rate at Nei-Mao-Pu station.

Suspended sediment volumetric concentration (ppm) Regression equation

\begin{tabular}{llll}
\hline$C<20$ & $Q_{s}=1.2370 \times 10^{-6} \times Q^{1.5851}$ & $(26.1)$ & $R^{2}=0.2841$ \\
$20 \leq C<150$ & $Q_{s}=4.0419 \times 10^{-5} \times Q^{1.1237}$ & $(26.2)$ & $R^{2}=0.7034$ \\
$150 \leq C<600$ & $Q_{s}=1.7650 \times 10^{-4} \times Q^{1.1620}$ & $(26.3)$ & $R^{2}=0.8052$ \\
$600 \leq C<1200$ & $Q_{s}=8.4370 \times 10^{-4} \times Q^{1.0023}$ & $(26.4)$ & $R^{2}=0.9442$ \\
$1200 \leq C<2500$ & $Q_{s}=1.6890 \times 10^{-3} \times Q^{1.000}$ & $(26.5)$ & $R^{2}=0.9343$ \\
$2500 \leq C<5500$ & $Q_{s}=4.4274 \times 10^{-3} \times Q^{0.9520}$ & $(26.6)$ & $R^{2}=0.9535$ \\
$5500 \leq C \leq 17397$ & $Q_{s}=1.1477 \times 10^{-2} \times Q^{0.9332}$ & $(26.7)$ & $R^{2}=0.8020$ \\
\hline
\end{tabular}


Table 4. Relationship between flow discharge and sediment transport rate at Tung-Tou station.

\begin{tabular}{lccc}
\hline $\begin{array}{l}\text { Suspended sediment } \\
\text { volumetric concentration } \\
(\mathrm{ppm})\end{array}$ & \multicolumn{2}{c}{ Regression equation } & $\begin{array}{c}\text { Correlation } \\
\text { coefficient }\end{array}$ \\
\hline$C<10$ & $Q_{s}=9.4561 \times 10^{-7} \times Q^{1.3353}$ & $(27.1)$ & $R^{2}=0.5411$ \\
$10 \leq C<50$ & $Q_{s}=2.0523 \times 10^{-5} \times Q^{1.0653}$ & $(27.2)$ & $R^{2}=0.8572$ \\
$50 \leq C<200$ & $Q_{s}=7.9632 \times 10^{-5} \times Q^{1.0449}$ & $(27.3)$ & $R^{2}=0.8687$ \\
$200 \leq C<400$ & $Q_{s}=2.3775 \times 10^{-4} \times Q^{1.0379}$ & $(27.4)$ & $R^{2}=0.9507$ \\
$400 \leq C<1000$ & $Q_{s}=4.7272 \times 10^{-4} \times Q^{1.0604}$ & $(27.5)$ & $R^{2}=0.9554$ \\
$1000 \leq C<4000$ & $Q_{s}=9.3300 \times 10^{-4} \times Q^{1.1560}$ & $(27.6)$ & $R^{2}=0.9198$ \\
$4000 \leq C<10000$ & $Q_{s}=2.995 \times 10^{-3} \times Q^{1.1246}$ & $(27.7)$ & $R^{2}=0.9560$ \\
$10000 \leq C \leq 32109$ & $Q_{s}=6.838 \times 10^{-3} \times Q^{1.1283}$ & $(27.8)$ & $R^{2}=0.9306$ \\
\hline
\end{tabular}

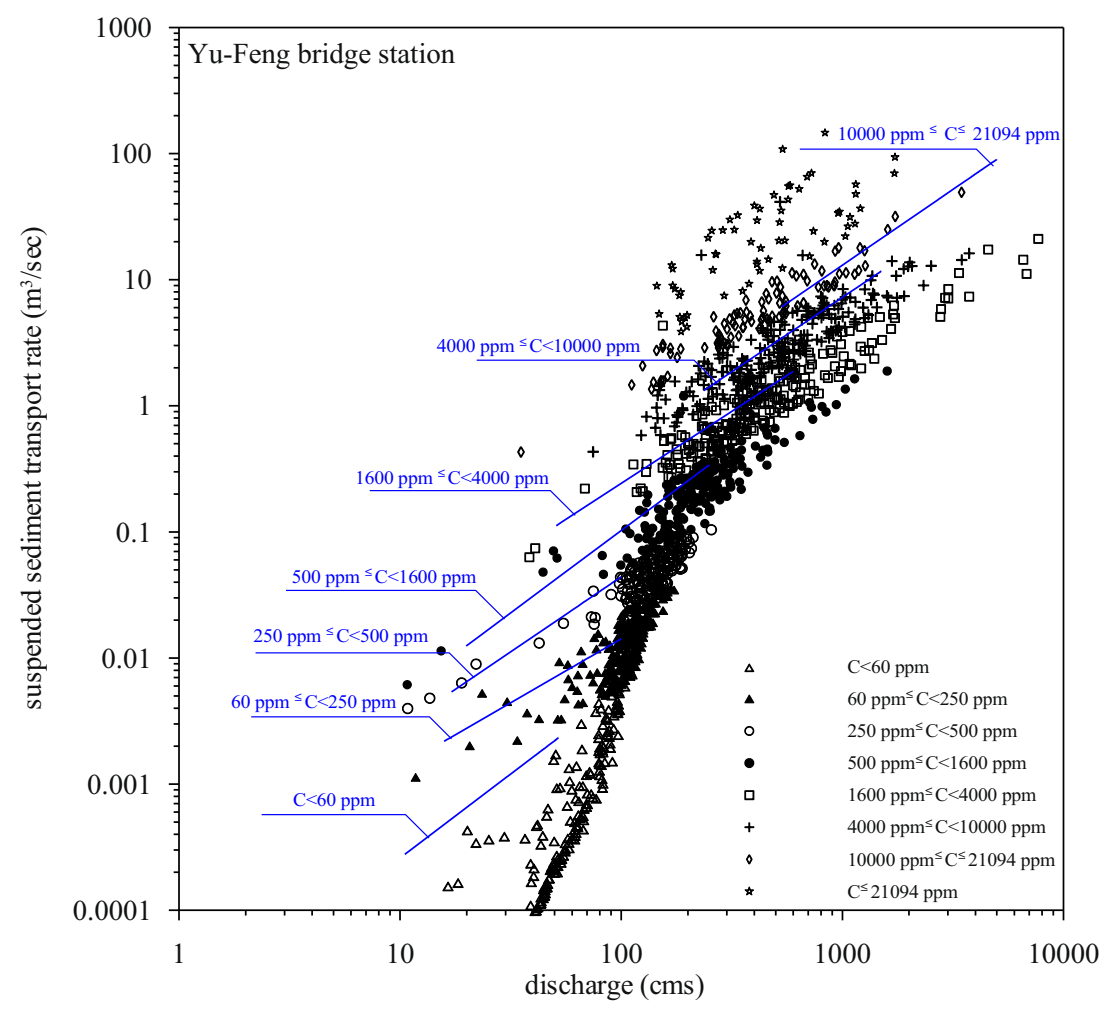

Figure 14. Comparison of the simulated and observed relationship between flow discharge and sediment transport rate at the Yu-Feng bridge station (40 rainfall events in 2007).

with the observed hydrographs of the following five hydrologic stations:

(1) Yu-Feng bridge station (Chou-Shui river subwatershed),

(2) Nei-Mao-Pu station (Chen-You-Lan river subwatershed),

(3) Tung-Tou station (Chin-Shui river subwatershed),

(4) Chang-Yun bridge station (Ching-Shui river subwatershed), and

(5) Tzu-Chiang bridge station (Chou-Shui river subwatershed).
Stations (1-3) are located in the upstream regions and stations (4) and (5) are located at the downstream regions of the Chou-Shui river basin. Figures 8-10 show the comparisons between simulated and observed discharge hydrographs at each station for the different typhoon events. These figures show that the shapes of the hydrographs may differ at different locations even for identical storm events due to unevenly distributed precipitation and heterogeneous physiographic properties. For example, single-peaked hydrographs were obtained for all five stations during the Typhoon 


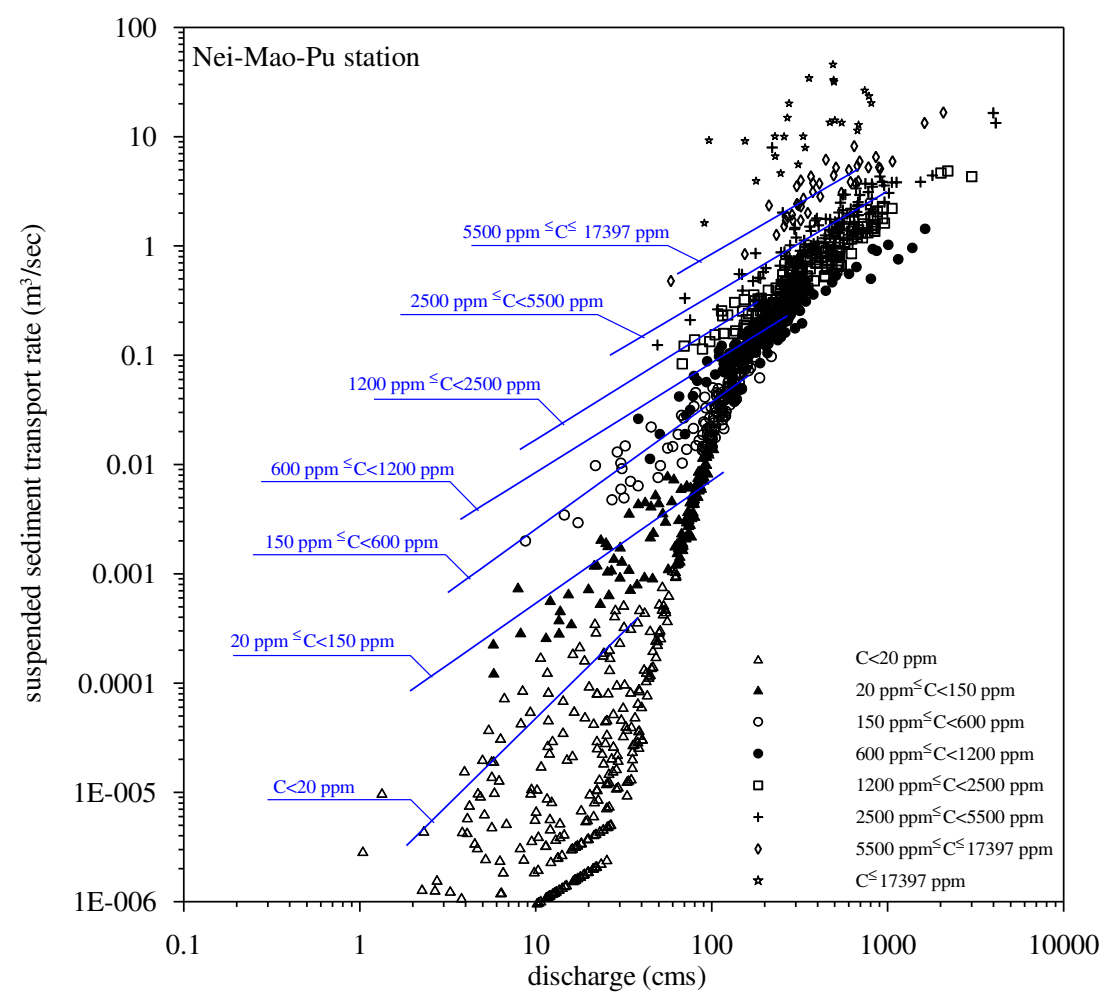

Figure 15. Comparison of the simulated and observed relationship between flow discharge and sediment transport rate at the Nei-Mao-Pu station (40 rainfall events in 2007).

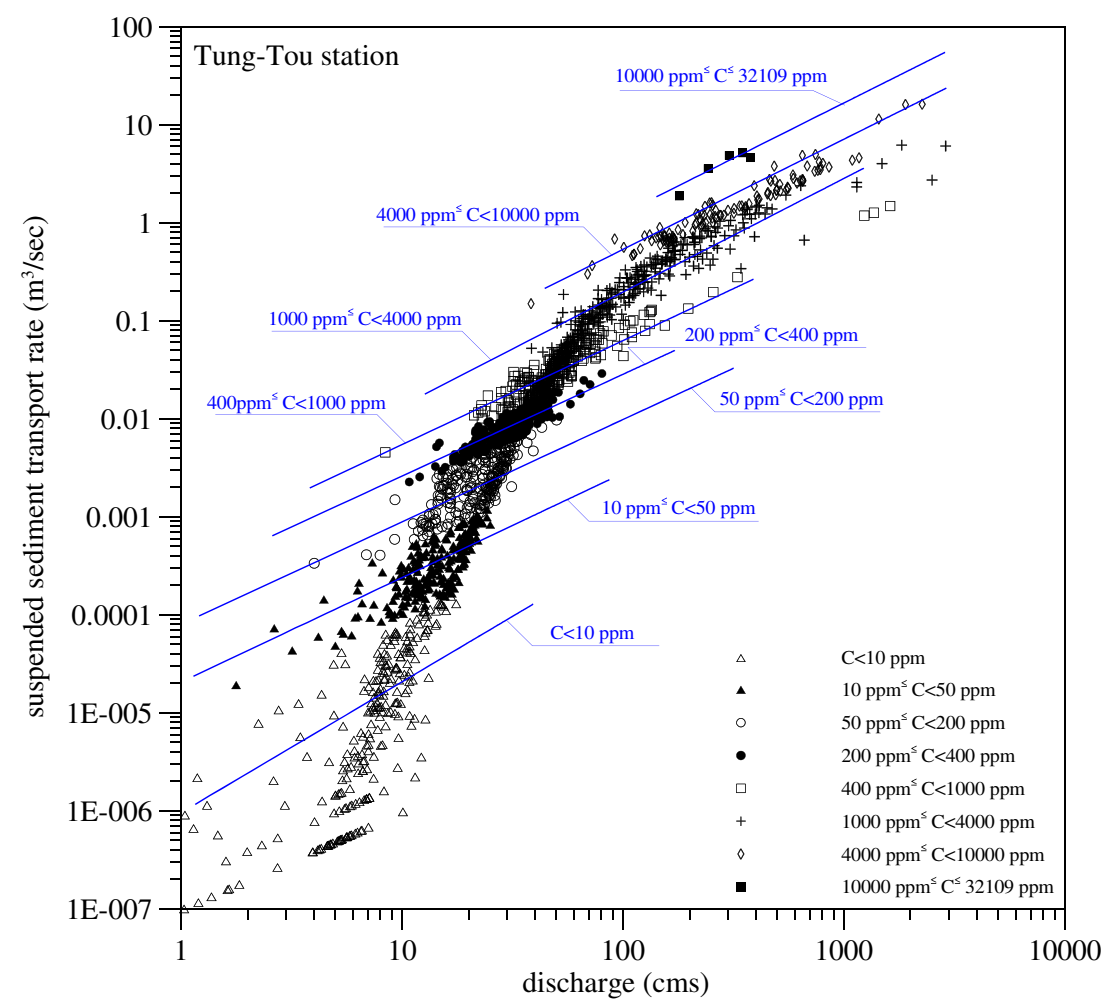

Figure 16. Comparison of the simulated and observed relationship between flow discharge and sediment transport rate at the Tung-Tou station (40 rainfall events in 2007). 
Herb event. However, during Typhoon Zeb, we observed four different shapes of hydrographs for four stations (discharge data from the Tzu-Chiang bridge station were not available). During Typhoon Nari, a single-peaked hydrograph was observed at $\mathrm{Yu}-\mathrm{Feng}$ bridge station and double-peaked hydrographs were obtained at Chang-Yun bridge station and Tung-Tou station. The discharge comparisons show that the timing and the discharge of peak flows are accurate and the shapes of hydrographs are well simulated. The results indicate that the proposed PSED model is applicable and reliable when simulating the rainfall-runoff process for basins with multiple subwatersheds.

\subsection{Comparisons between simulated and measured suspended sediment transport rates}

Observations of suspended sediment concentration at hydrological stations are sparse, especially during typhoon and storm events due to safety concerns. Therefore, we were not able to directly validate the suspended sediment concentrations. However, we can compare the simulated relationship with the observed relationship between discharge and suspended sediment transportation rate. Yu-Feng bridge, Nei-Mao-Pu and Tung-Tou stations have relative abundance of observed suspended sediment concentration data.

In order to understand the relation between flow and sediment transport, regression analyses on the observed data obtained at Yu-Feng bridge, Nei-Mao-Pu, and Tung-Tou stations are conducted in this study. The results are shown in figures 1113. Although there is no obvious one-to-one relationship between flow discharge and sediment transport rate, correlation exists between these two variables and the correlation is dependent on hydrological and physiographic conditions of basins. Generally, large relative variations in suspendedsediment discharge or concentration occur at low to medium discharge, and the distribution of observed sediment transport is more scattered. At high discharge, relative variations in the observations diminished appreciably, and the distribution of observed sediment transport is more concentrated (American Society of Civil Engineers 1975). To minimize errors in the resulting relationship between flow and sediment transport, different equations for flows of various sizes were used in the regression analyses, as those shown in tables $2-4$ and figures 11-13.

Figures 11-13 show this relationship at Yu-Feng bridge, Nei-Mao-Pu, and Tung-Tou stations, respectively. Tables $2-4$ list the regression equations and correlation coefficients for the observed relationship at these three stations. In tables, $Q$ is the flow discharge $\left(\mathrm{m}^{3} / \mathrm{s}\right), Q_{s}$ is the transportation rate of suspended sediment $\left(\mathrm{m}^{3} / \mathrm{s}\right)$. The correlation coefficients of the regression equations (25-27) are larger than 0.8 for high flow discharge but not for the equations with small flow discharge and low sediment concentration. These results indicate that equations (25-27) are capable of describing the relationship between flow discharge and sediment transport rate.

Figures 14-16 show the comparison between the simulated relationship and the observed relationship for 40 rainfall events in 2007 at the aforementioned three hydrologic stations, respectively. The solid lines represent the relationship between measured flow discharge and sediment transport rate at various ranges of suspended sediment concentrations. Due to the lack of measured data under severe conditions of high flow discharge and high sediment concentration, part of the simulation results fell outside the extended part of the regression equation where the simulated concentrations larger than the greatest measured value were denoted by a ' 2 ' in figures 14-16. Besides these outlying simulated values, the relationships between simulated flow discharge and sediment

Table 5. Comparison of sediment yield calculated using the PSED model and the regression equation obtained from the observed data for Yu-Fung bridge station (unit: $\mathrm{m}^{3}$ ).

\begin{tabular}{lccc}
\hline $\begin{array}{l}\text { Sediment } \\
\text { Yield }\end{array}$ & $\begin{array}{c}\text { Typhoon } \\
\text { Herb }\end{array}$ & $\begin{array}{c}\text { Typhoon } \\
\text { Zeb }\end{array}$ & $\begin{array}{c}\text { Typhoon } \\
\text { Nari }\end{array}$ \\
\hline PSED model & $29,554,847$ & $3,853,276$ & 675,122 \\
Equation (25) & $32,641,206$ & $4,189,138$ & 621,658 \\
Relative error (\%) & 9.46 & 8.02 & 8.60 \\
\hline
\end{tabular}

Table 6. Comparison of sediment yield calculated using the PSED model and the regression equation obtained from the observed data for Nei-Mao-Pu station (no observation sediment concentration data available during Typhoon Nari) (unit: $\left.m^{3}\right)$.

\begin{tabular}{lcc}
\hline Sediment Yield & Typhoon Herb & Typhoon Zeb \\
\hline PSED model & $5,563,125$ & 204,857 \\
Equation (26) & $6,138,421$ & 189,632 \\
Relative error (\%) & 9.37 & 8.03 \\
\hline
\end{tabular}

Table 7. Comparison of sediment yield calculated using the PSED model and the regression equation obtained from the observed data for Tung-Tou station (unit: $\mathrm{m}^{3}$ ).

\begin{tabular}{lccc}
\hline $\begin{array}{l}\text { Sediment } \\
\text { Yield }\end{array}$ & $\begin{array}{c}\text { Typhoon } \\
\text { Herb }\end{array}$ & $\begin{array}{c}\text { Typhoon } \\
\text { Zeb }\end{array}$ & $\begin{array}{c}\text { Typhoon } \\
\text { Nari }\end{array}$ \\
\hline PSED model & $2,881,425$ & $1,047,226$ & $1,749,207$ \\
Equation $(27)$ & $2,608,714$ & 939,563 & $1,592,934$ \\
Relative error $(\%)$ & 10.45 & 11.46 & 9.81 \\
\hline
\end{tabular}


transport rate are in good agreement with the regression equations generated with observed data, especially when the flow discharges are relatively large.

\subsection{Sediment yield}

To estimate sediment yield, the PSED model multiplies the simulated discharge with the simulated concentration of suspended sediment. However, we can also obtain the sediment yield by substituting the observed discharge into regression equations (25-27). We estimated sediment yield for the three typhoon events. Tables 5-7 show comparisons of sediment yield calculated using these two approaches. The results show that when using the PSED model, the largest relative error for all stations during the three typhoon events was $11.46 \%$. This indicates that the PSED model can provide a reliable estimation of sediment yield.

Table 8. Annual sediment yield estimated by the PSED model at the hydrologic stations in the Chou-Shui river basin in 2007 (unit: $\mathrm{m}^{3}$ ).

\begin{tabular}{lccccc}
\hline Hydrological station & Yu-Fung bridge & Nei-Mao-Pu & Tung-Tou & Chang-Yun bridge & Tzu-Chiang bridge \\
\hline Annual sediment yield & $14,833,736$ & $8,861,554$ & $8,708,801$ & $26,059,639$ & $29,381,175$ \\
\hline
\end{tabular}

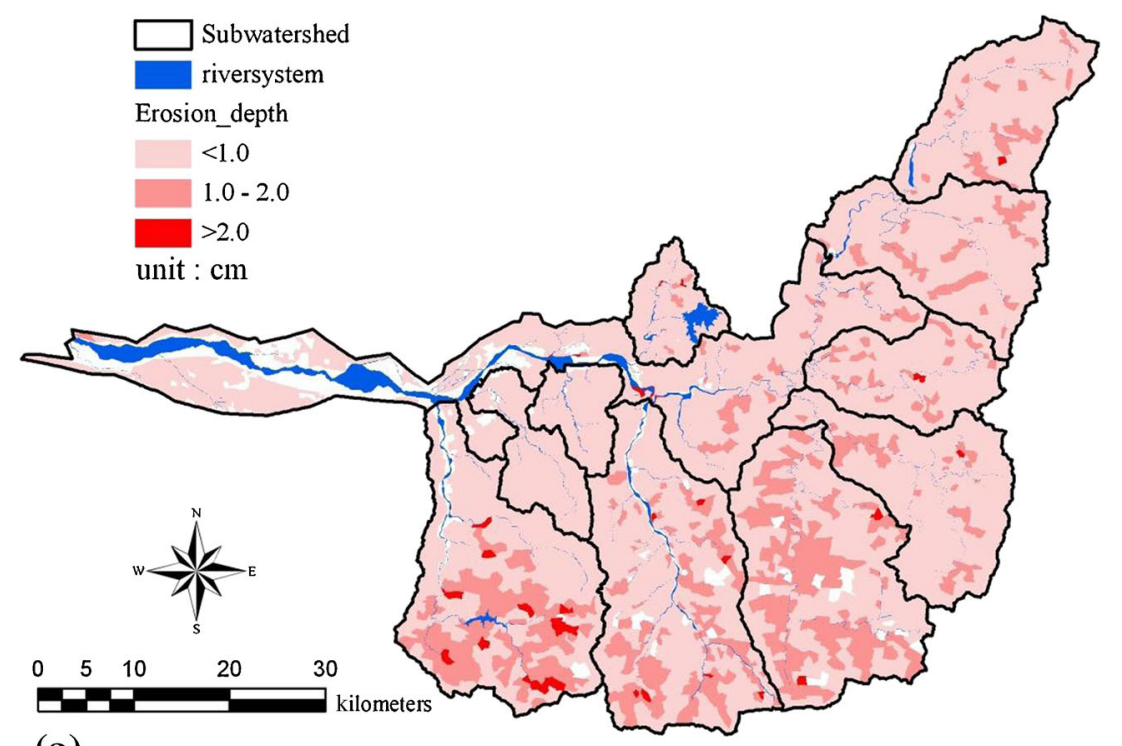

(a)

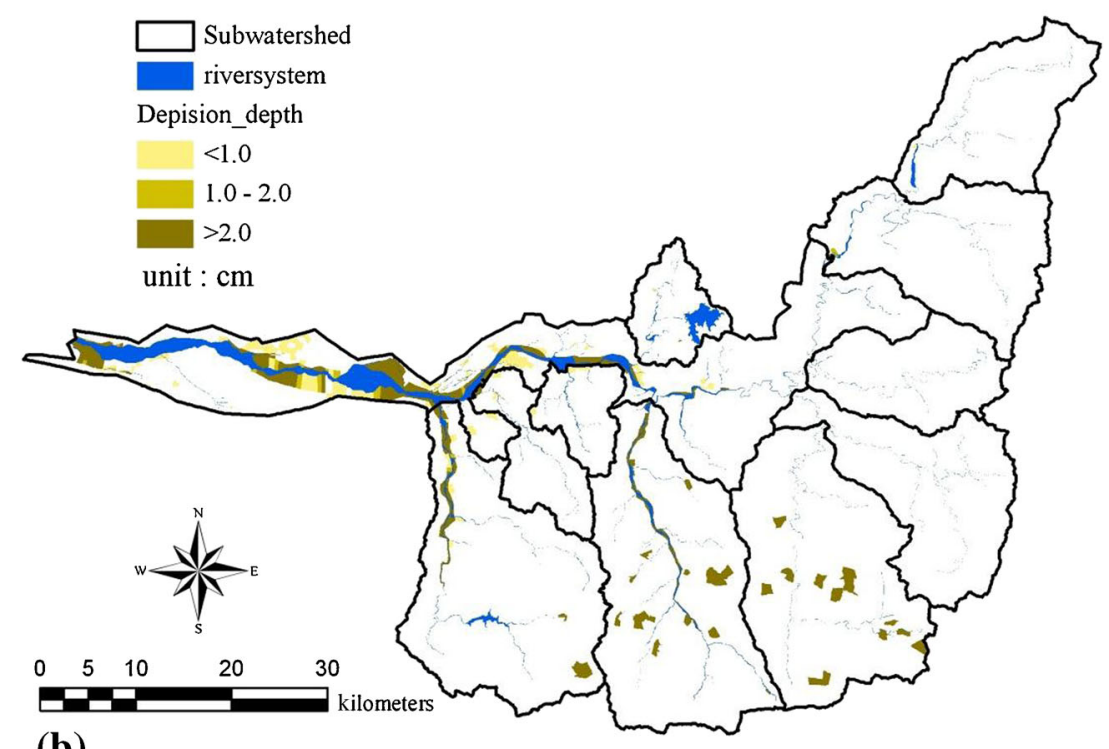

(b)

Figure 17. (a) Erosion distribution and (b) deposition distribution of the Chou-Shui river basin during Typhoon Herb. 
We further use the PSED to estimate sediment yield for the 40 rainfall events, in 2007, at each hydrologic station. The annual sediment yield in 2007 can be estimated by summing sediment yield caused by each rainfall event. Table 8 shows the annual sediment yield at each station in 2007. The annual sediment yield estimation $\left(29,381,175 \mathrm{~m}^{3}\right)$ of the Tzu-Chiang bridge station can be used as an approximation of the total annual sediment yield of the entire Chou-Shui river basin for 2007.

Although the sediment yield can be calculated using the regression equations, data from the hydrologic stations were not available for all subwatersheds. In addition, the observed data may not be complete for all typhoon and rainfall events, especially for the observed suspended sediment concentration data. The occurrence of insufficient data can be common, especially for events that have high flow discharge and high concentrations. Therefore, the proposed PSED model is a very powerful tool for calculating the sediment yield for each subwatershed as well as the entire basin. In addition, the results generated by the PSED model can provide supplementation for insufficient data.

\subsection{Soil erosion and distribution}

The soil erosion is calculated based on variations in the bed elevation which can be obtained using equation (23). Figures 17-19 show the spatial

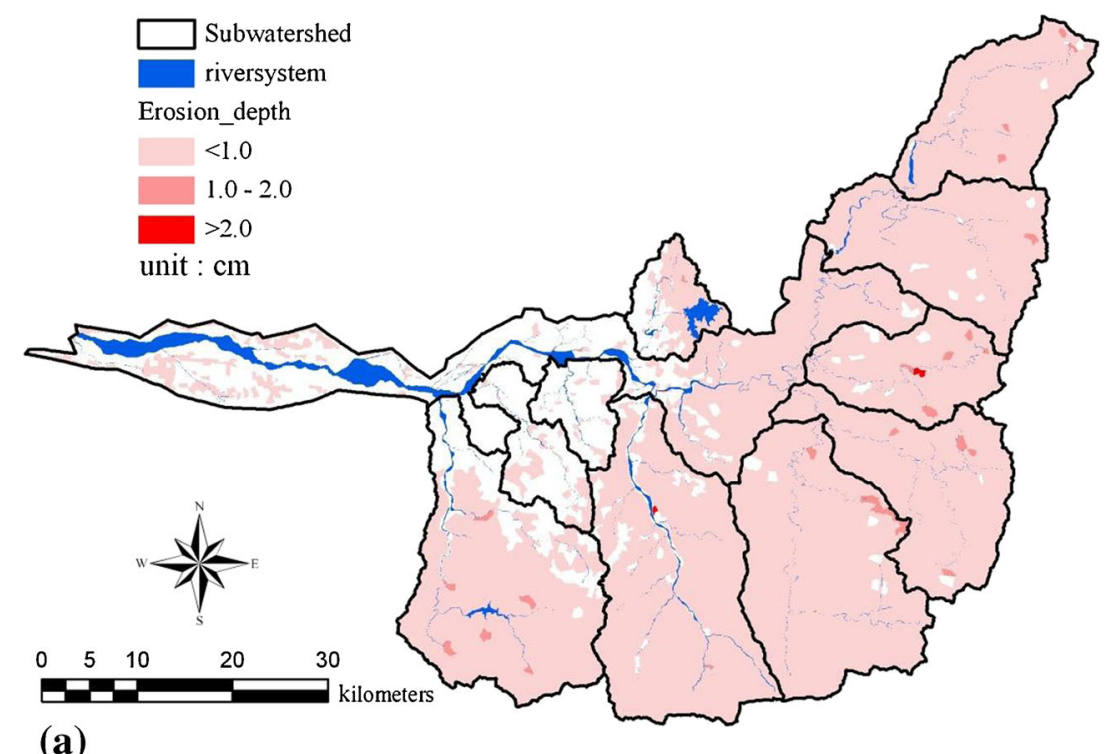

(a)

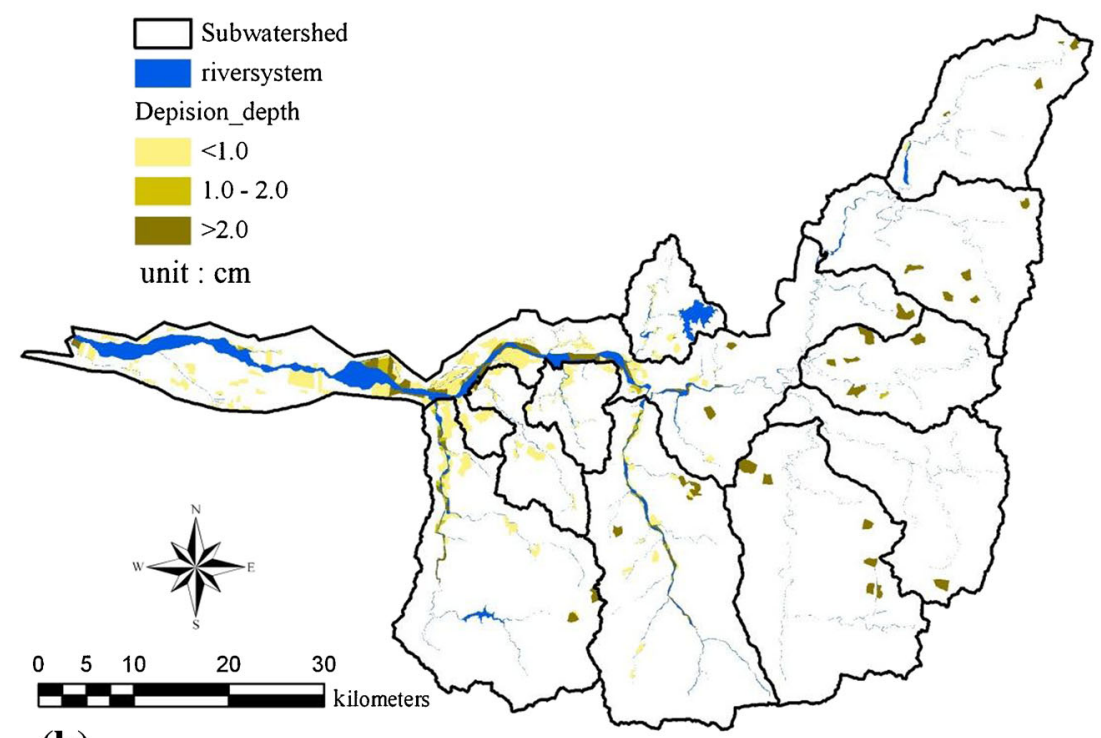

(b)

Figure 18. (a) Erosion distribution and (b) deposition distribution of the Chou-Shui river basin during Typhoon Zeb. 


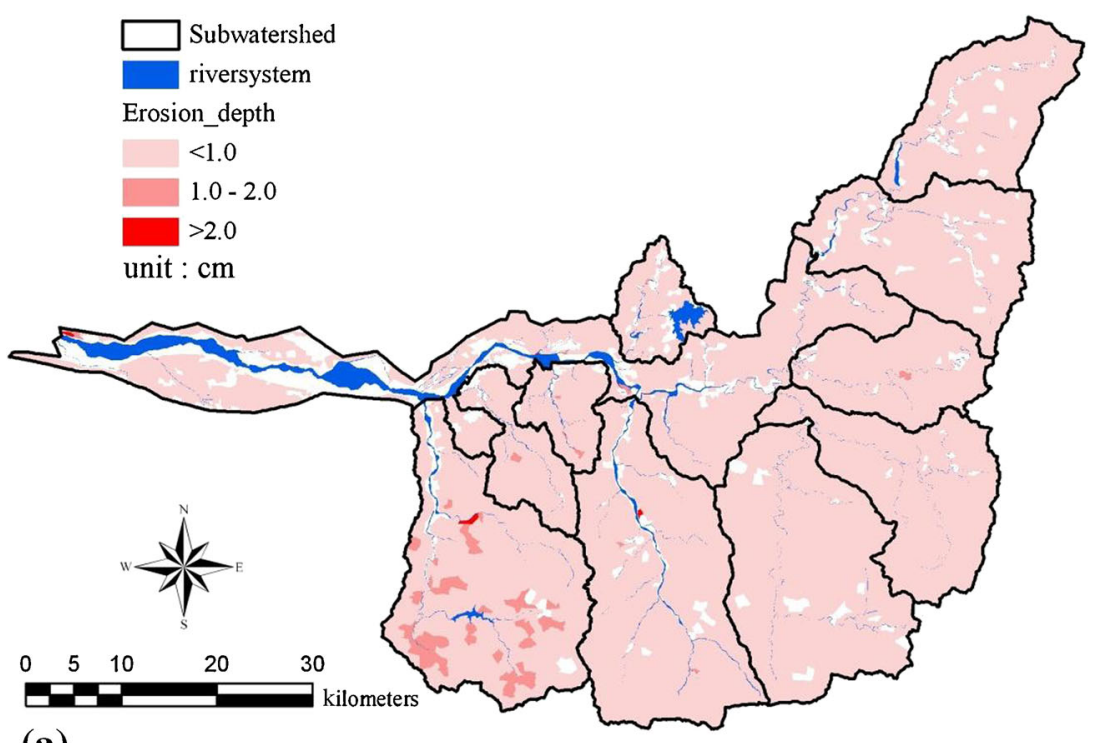

(a)

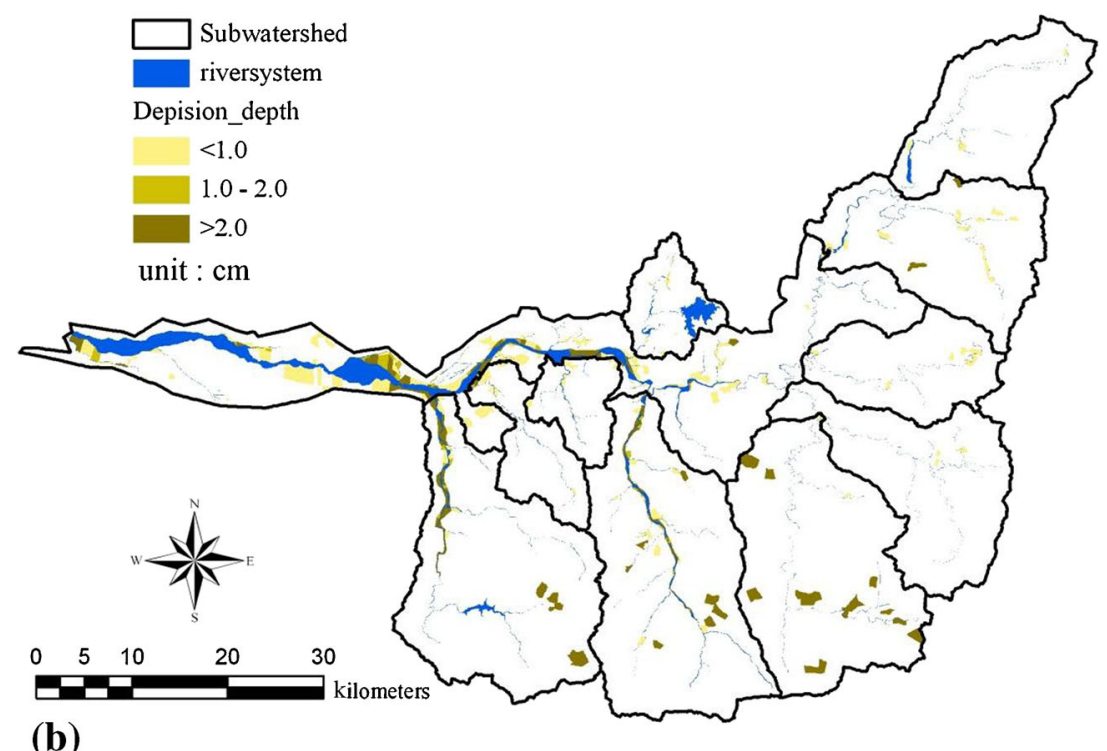

(b)

Figure 19. (a) Erosion distribution and (b) deposition distribution of the Chou-Shui river basin during Typhoon Nari.

distribution of erosion during the three typhoon events. From these figures, we notice that severely eroded cells lie mainly in the areas which have less vegetation and steeper slopes. The eroded sediment is transported by overland flow or river flow and then deposited on the areas which have flatter slopes, usually on the two sides of a river. These figures, which describe spatial distribution of areas prone to soil erosion, are useful to identify areas of sediment sources within the basin with multiple subwatersheds. The severely eroded areas need special priority for the implementation of soil erosion control installations. The soil erosion of a cell is calculated by multiplying the change in bed elevation with the cell area. Summing the soil erosion at all cells will result in the total soil erosion of the basin during a typhoon or the rainfall event. The annual soil erosion is the accumulation of erosion over the course of the year. Figure 20 shows the erosion distribution as a result of 40 rainfall events in 2007. The annual soil erosion of 2007 in the Chou-Shui river basin was $67,049,692 \mathrm{~m}^{3}$. According to the sediment yield in 2007, the averaged sediment delivery ratio (SDR) of the entire Chou-Shui river basin is about $43.82 \%$. The SDR result estimated by the PSED model is similar to the findings of Chen and Lai (1999), which indicate the SDR of Chou-Shui river basin is about $44.91 \%$. 


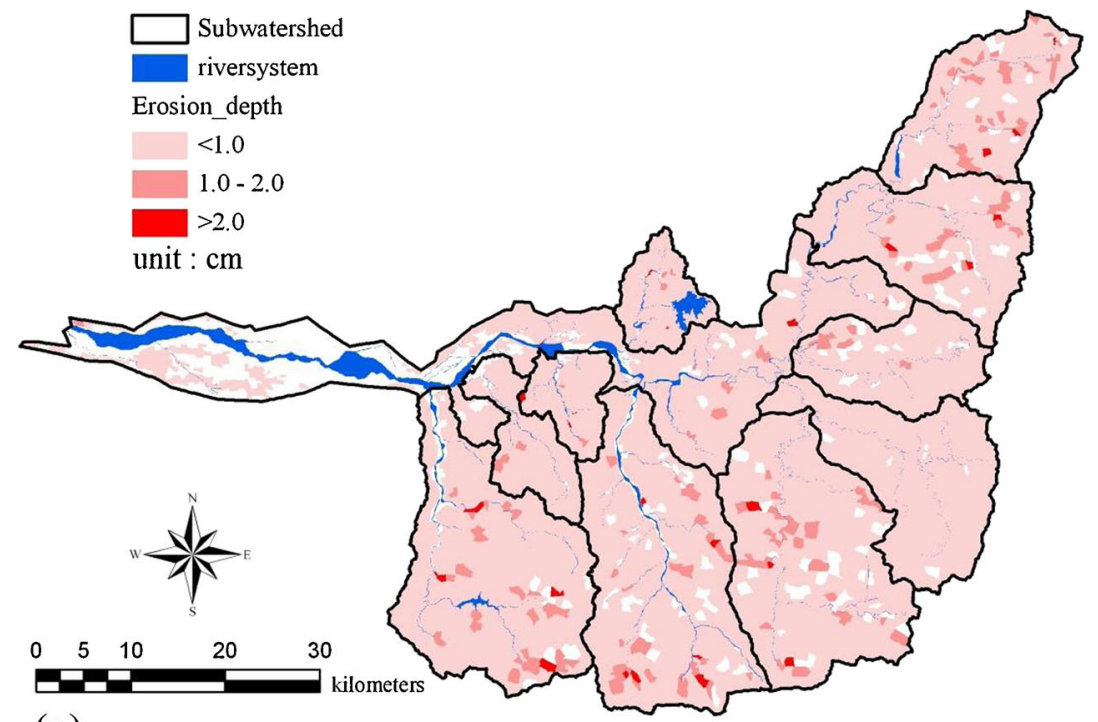

(a)
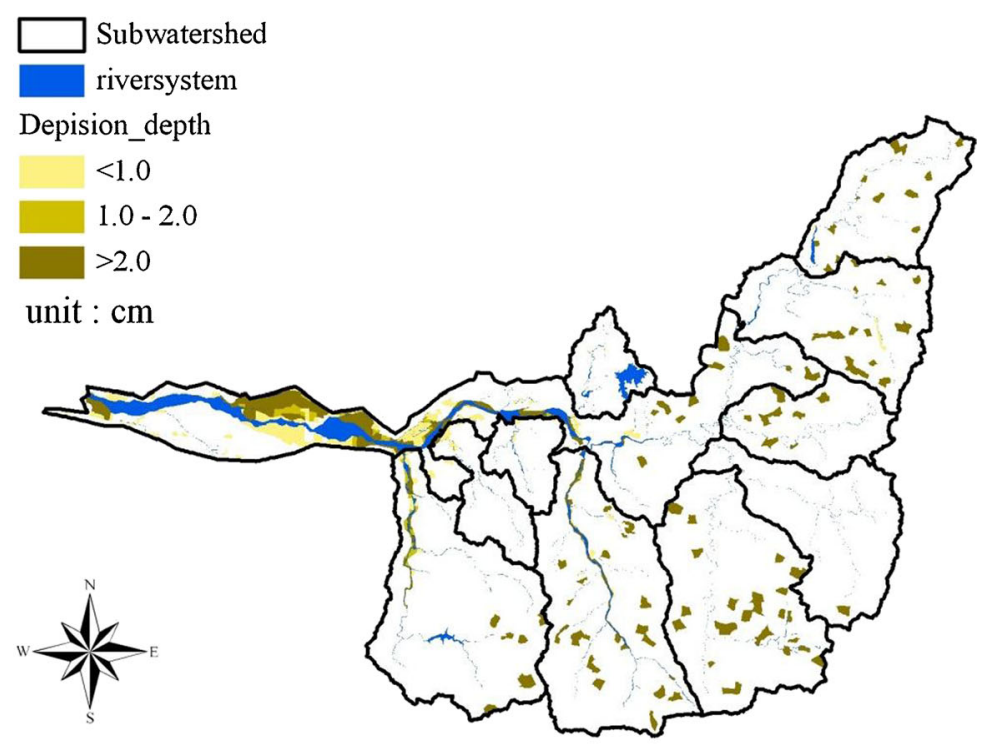

$\begin{array}{lllll}0 & 5 & 10 & 20 & 30\end{array}$

kilometers

(b)

Figure 20. (a) Erosion distribution and (b) deposition distribution of the Chou-Shui river basin in year 2007.

\section{Conclusions}

With the assistance of GIS, we coupled a physiographic rainfall-runoff model with a soil erosiondeposition model to develop a PSED model. The PSED model can simulate flow discharge, suspended sediment transportation rate, soil erosion, sediment yield, and spatial distribution of soil erosion in a large-scale basin. We first verified the rainfall-runoff model using three typhoon events. The simulated results agree favourably with the observed characteristics of the hydrographs including the shape of the hydrograph, the peak flow discharge, and the timing of the peak flow. We were not able to directly verify the soil erosiondeposition model by comparing simulated and observed suspended sediment concentration values due to the lack of observation data during rainfall events. Therefore, we applied a regression analysis to define the relationship between the discharge and the suspended sediment transport rate for both simulated results and observed data. Instead of comparing the discharge and suspended sediment concentration directly, we compared the model predicted relationship with the observed relationship to verify the soil erosion-deposition model. The simulation results agree favourably with the observations, in terms of the aforementioned 
relationship, for a total of 37 rainfall events in 2007.

The results show that the PSED model can provide accurate and reliable simulations of flow discharge and concentrations of suspended sediment. For estimation of sediment yield, we compared the sediment yield simulated using the PSED model with the sediment yield obtained from the regression equations and observed data. The relative errors associated with the sediment yield are reasonably small. Furthermore, we obtained the erosion distribution based on changes in bed elevation at each cell. This study demonstrates the applicability, accuracy, and reliability of the PSED model for simulation of flow discharge, suspended sediment transport rate, sediment yield, and erosion distribution in a river basin. Because of these characteristics, the PSED model may be useful for managing the basin.

\section{References}

American Society of Civil Engineers 1975 Sedimentation Engineering; pp. 472-476.

ASTM Standards D3977 2007 Standard Test Methods for Determining Sediment Concentration in Water Samples; http://www.astm.org.

Beasley D B, Huggins L F and Monke E J 1980 Answers: A model for watershed planning; Trans. Am. Soc. Agric. Eng. 23(4) 938-944.

Bhattarai R and Dutta D 2007 Estimation of soil erosion and sediment yield using GIS at catchment scale; Water Resour. Manag. 21 1635-1647.

Brazier R E, Beven K J, Freer J and Rowan J S 2000 Equifinality and uncertainty in physically-based soil erosion models: Application of the GLUE methodology to WEPP, the Water Erosion Prediction Project for sites in the UK and USA; Earth Surf. Proc. Land. 25 825-845.

Chen S C and Lai I C 1999 Estimating the sediment delivery ratio of the watershed; J. Chinese Soil Water Conserv. 30(1) $47-57$.

Chen C N, Tsai C H and Tsai C T 2004 A study of GIS linked physiographic soil erosion-deposition model for watershed; J. Chinese Institute Civil Hydraul. Eng. 16(3) 379-391.

Chen C N, Tsai C H and Tsai C T 2006 Simulation of sediment yield from watershed by physiographic soil erosion-deposition model; J. Hydrol. 327 293-303.

Chen C N, Tsai C H and Tsai C T 2011 Simulation of runoff and suspended sediment transport rate in a basin with multiple watersheds; Water Resour. Manage. 25 793-816.

Chow V T, Maidment D R and Mays L W 1988 Applied Hydrology; McGraw-Hill: New York, pp. 153-155.

Edwards T K and Glysson G D 1999 Techniques of water resources investigations of the US Geological Survey: Chapter 2. Field Methods Measurement of Fluvial Sediment, Virginia, USA.

Fu G, Chen S and McCool D K 2006 Modeling the impacts of no-till practice on soil erosion and sediment yield with RUSLE, SEDD, and ArcView GIS; Soil Till Res. 85 38-49.

Hu S C, Lu J Y, Wu I Y and Chen T F 1995 Interrill erosion rates of high clay soils in Lien-Hua-Chi area; Bull. Taiwan Forestry Res. Inst. 10(1) 33-40.
Itakura T and Kishi T 1980 Open channel flow with suspended sediments; J. Hydraul. Div. 106(8) 13251343.

Jain M K, Kothyari U C and Raju K G R 2005 GIS based distributed model for soil erosion and rate of sediment outflow from catchments; J. Hydraul. Eng. 131(9) $755-769$.

Knisel W G 1980 CREAMS: A field scale model for chemicals, runoff and erosion from agricultural management systems; USDA, Conservation Research Report 26.

Ma M M 1995 The rainfall characteristics and erosivity in central and northern areas of Taiwan; Master Thesis, Department of Civil Engineering; National Chung-Hsing University, Taiwan.

Misra R K and Rose C W 1990 Annual for use of program GUEST; Division of Australian Environmental Studies Report, Griffith University, Brisbane, Qld.

Morgan R P C, Quinton J N, Smith R E, Govers G, Poesen J W A, Auerswald K, Chisci G, Torri D and Styczen M E 1998 The European soil erosion model (EUROSEM): A process-based approach for predicting sediment transport from fields and small catchments; Earth Surf. Proc. Land. 23 527-544.

Murakami S, Hayashi S, Kameyama S and Watanabe M 2001 Fundamental study on sediment routing through forest and agricultural area in watershed; Ann. J. Hydraul. Eng. 45 799-804 (in Japanese).

Mutchler C K and Young R A 1975 Soil detachment by raindrops: In: Proceedings of Sediment-yield Workshop, ARS-S-40, USDA.

Nearing M A, Foster G R, Lane L J and Finkner S C 1989 A process-based soil erosion model for USDA - Water erosion prediction project technology; Trans. Am. Soc. Agric. Eng. 32(5) 1587-1593.

Paringit E C and Nadaoka K 2003 Sediment yield modelling for small agricultural catchments: Land-cover parameterization based on remote sensing data analysis; Hydrol. Process. 17 1845-1866.

Renard K G, Foster G R, Weesies G A and Porter J P 1991 RUSLE, Revised Universal Soil Loss Equation; J. Soil Water Conserv. 16(1) 30-33.

Ricker M C, Odhiambo B K and Church J M 2008 Spatial analysis of soil erosion and sediment fluxes: A paired watershed study of two Rappahannock river tributaries, Stafford County, Virginia; Environ. Manag. 41 766778.

Rose C W, Williams J R, Sander G C and Barry D A 1983 A mathematical model of soil erosion and deposition process I: Theory for a plane element; Soil Sci. Soc. Am. J. 47 991-995.

Sheh C S and Wang M K 1991 An atlas of major soils of Taiwan and a general map of soils in Taiwan (Scale 1: 250,000); Council of Agriculture, Taiwan.

Shimizu Y, Yamaguchi H and Itakura T 1990 Threedimensional computation of flow and bed deformation; J. Hydraul. Div. 116(9) 1090-1108.

Sun H, Cornish P S and Daniell T M 2002 Contourbased digital elevation modeling of watershed erosion and sedimentation: Erosion and sedimentation estimation tool (EROSET); Water Resourc. Res. 38(11) $1-10$.

Tsai C T and Tsai C H 1997 A study on the applicability of discharge formulas for trapezoidal broad-crested weirs; J. Taiwan Water Conserv. 45(2) 29-45.

Wang Y M, Tfwala S S, Chan H C and Lin Y C 2013 The effects of sporadic torrential rainfall on suspended sediments; Archives Sci. 66(5) 211-224.

Williams J R 1975 Sediment routing for agricultural watersheds; Water Resour. Bull. 11 965-974. 
Williams J R, Jones C A and Dyke P T 1984 A modeling approach determining the relationship between erosion and soil productivity; Trans. Am. Soc. Agric. Eng. 27 129-144.

Wischmeier W H and Smith D D 1978 Predicting Rainfall Erosion Losses - A Guide to Conservation Planning; USDA, Agriculture Handbook No. 537: 58.

Wongsa S, Nakui T, Iwai M and Shimizu Y 2002 Runoff and sediment transport modeling for mountain river; In: Proceeding of River Flow 2002 - International Conference on Fluvial Hydraulic Belgium, pp. 683-691.
Wu C H, Chen C N, Tsai C H and Tsai C T 2012 Estimating sediment deposition volume in a reservoir using the physiographic soil erosion-deposition model; Int. J. Sedim. Res. 27 362-377.

Young R A, Onstad C A, Bosch D D and Andersen W P 1989 AGNPS: A nonpoint-source pollution model for evaluating agricultural watersheds; J. Soil Water Conserv. 44 $168-173$.

Yuan Z J, Cai Q G and Chu Y M 2007 A GIS-based distributed soil erosion model: A case study of typical watershed, Sichuan basin; Int. J. Sedim. 22(2) 120-130.

MS received 28 July 2013; revised 18 May 2014; accepted 29 May 2014 